\title{
The estimation of $\mathrm{CO}_{2}$ storage potential of a gas-bearing shale succession at the early stage of reservoir characterization: a case study from the Baltic Basin (Poland)
}

\author{
Adam WÓJCICKI ${ }^{1, *}$, Marek JAROSIŃSKI ${ }^{1}$ and Michał Grzegorz ROMAN ${ }^{1}$ \\ 1 Polish Geological Institute - National Research Institute, Rakowiecka 4, 00-975 Warszawa, Poland
}

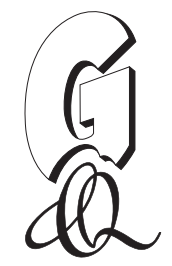

Wójcicki, A., Jarosiński, M., Roman, M.G., 2021. The estimation of $\mathrm{CO}_{2}$ storage potential of a gas-bearing shale succession
at the early stage of reservoir characterization: a case study from the Baltic Basin (Poland). Geological Quarterly, 65: 3, doi: 10.7306/gq. 1571

Estimation of the $\mathrm{CO}_{2}$ storage potential of gas-bearing shales in the Lower Paleozoic Baltic Basin is at an early stage of reservoir exploration and production, based on data from one vertical exploration borehole, supplemented with some information from adjacent boreholes. The borehole section examined is $120 \mathrm{~m}$ long and comprises three intervals enriched with organic matter separated by organic-poor intervals. In our approach, the storage capacity is represented by: (1) sorption potential of organic matter, (2) open pore space and (3) potential fracture space. The potential for adsorbed $\mathrm{CO}_{2}$ was determined from Langmuir isotherm parameters taken from laboratory measurements and recalculated from $\mathrm{CH}_{4}$ adsorption curves. The pore space capacity was estimated in two ways: by utilizing results of laboratory measurements of dynamic capacity for pores $>100 \mathrm{~nm}$ and using results of helium porosimetry, the first of these being considered as the most relevant. Due to the low permeability of the shale matrix we have adopted the standard assumption that the $\mathrm{CO}_{2}$ is able to reach effectively only $10 \%$ of the theoretical total sorption and pore volume. For hydraulic fracture space, the theoretical maximum opening of vertical fractures in the direction of minimum horizontal stress was considered, decreased by the expected portion of fracturing fluid flowback and by partial fracture closure by burial compaction. The effectiveness of three $\mathrm{CO}_{2}$ storage categories for the individual organic-rich and organic-poor shale units shows an obvious positive correlation of TOC content with the storage efficiency by sorption and within pore space, and a negative correlation with the storage efficiency in hydraulic fractures. It was estimated that sorption, over the maximum storage interval ( $120 \mathrm{~m}$ thick), is responsible for $\sim 76 \%$ of total storage capacity, pore space accounts for $13 \%$ (for the most relevant porosity model) while the contribution of fractures is $\sim 11 \%$. In the minimum storage interval (35 $\mathrm{m}$ thick, including the best quality shales) the estimated proportions of sorption, pore space and fractures in the total storage capacity are 84,10 and $6 \%$ respectively. Finally, the result for the best quality storage interval ( $35 \mathrm{~m}$ thick) was compared with the Marcellus Shale of similar thickness (average $\sim 38 \mathrm{~m}$ ) and with other options of $\mathrm{CO}_{2}$ storage in Poland. The most organic-rich units in the area studied have a $\mathrm{CO}_{2}$ storage capacity efficiency (i.e. storage capacity per volume unit of shale) only slightly less than average for the Marcellus Shale, because sorption capacity - the dominant component - is comparable in both cases. However, the open pore space capacity in the Marcellus Shale appears to be far higher, even if the potential fracture space calculated for the borehole studied is taken into consideration, probably because the free gas content in the Marcellus Shale is far higher than in the Baltic Basin. $\mathrm{CO}_{2}$ storage in depleted shale gas wells is not a competitive solution compared to storage in saline aquifer structures or in larger hydrocarbon fields.

Key words: carbon dioxide, storage capacity assessment, shale gas reservoir, sorption, pores, fractures

INTRODUCTION

The rapid development of unconventional hydrocarbon resources has changed the energy-political landscape of the world and opened new opportunities for underground storage of carbon dioxide $\left(\mathrm{CO}_{2}\right)$. In conventional $\mathrm{CO}_{2}$ storage, in saline aquifers or depleted hydrocarbon fields, supercritical $\mathrm{CO}_{2}$ is injected into a permeable and porous rock which is often covered by tight shale layers playing the role of caprock. In a shale reservoir, the rock matrix is almost impermeable, and the final stor-

\footnotetext{
* Corresponding author, e-mail: awojci@pgi.gov.pl
}

Received: April 15, 2020; accepted: October 26, 2020; first published online: December 14, 2020 age space is possible to access using natural and technologically induced fractures whose conductivity is stimulated by hydraulic fracturing at the gas exploitation stage. Storage in shales is a relatively new idea, which follows the onset of industry-scale gas production from unconventional tight shale rocks (Kang et al., 2011; Godec et al., 2013b, 2014), and has not yet been implemented in practice.

In spite of the limited storage space in gas-bearing shales, the large extent of shale reservoirs means that they are considered a viable place for $\mathrm{CO}_{2}$ sequestration (Godec et al., 2013a). From the safety point of view, shale has good sealing properties that indicates a potential for near-permanent entrapment of $\mathrm{CO}_{2}$. Pressure and temperature conditions in shale reservoirs are always sufficient to keep $\mathrm{CO}_{2}$ in the dense supercritical state that occurs above $7.4 \mathrm{MPa}$ and $31^{\circ} \mathrm{C}$ (IPCC, 2005). For example, at a depth of storage in a research borehole of 
Properties of methane and carbon dioxide, controlling their ability to concentrate and their mobility in shale (Trengove and Wakeham, 1987; Kurniawan et al., 2006)

\begin{tabular}{|l|c|c|c|c|}
\hline & $\begin{array}{c}\text { Density at } 20^{\circ} \mathrm{C} \\
0.1 \mathrm{MPa}\left[\mathrm{kg} / \mathrm{m}^{3}\right]\end{array}$ & $\begin{array}{c}\text { Molecular mass } \\
{\left[\mathrm{g} \mathrm{mol}^{-1}\right]}\end{array}$ & $\begin{array}{c}\text { Solubility in water at } 25^{\circ} \mathrm{C}, \\
0.1 \mathrm{MPa}\left[\mathrm{mg} \mathrm{^{-1 }}\right]\end{array}$ & $\begin{array}{c}\text { Molecular size } \\
{[\mathrm{nm}]}\end{array}$ \\
\hline Methane $\mathrm{CH}_{4}$ & 0.6556 & 16.04 & 22.7 & $\begin{array}{c}0.38 \\
\text { (tetrahedron side) }\end{array}$ \\
\hline Carbon dioxide $\mathrm{CO}_{2}$ & 1.977 & 44.01 & 1450 & $\begin{array}{c}0.33 \\
\text { (linear) }\end{array}$ \\
\hline
\end{tabular}

$<3500 \mathrm{~m}$, and for a low temperature gradient, $\mathrm{CO}_{2}$ has a density close to $800 \mathrm{~kg} / \mathrm{m}^{3}$.

Due to its physical properties, $\mathrm{CO}_{2}$ is a perfect agent for stimulation of methane $\left(\mathrm{CH}_{4}\right)$ production from ultra-tight shale reservoirs, as well as from conventional reservoirs. Firstly, a higher $\mathrm{CO}_{2}$ (than $\mathrm{CH}_{4}$ ) adsorption affinity to organic matter and clay minerals leads to $\mathrm{CH}_{4}$ replacement by $\mathrm{CO}_{2}$ in organic matter and other mineral pore surfaces (Heller and Zoback, 2014; Zhou et al., 2019). This mechanism produces an active push of gas off the reservoir and ensures permanent bonding of $\mathrm{CO}_{2}$ in the shale volume. The $\mathrm{CO}_{2}$ molecule is smaller than hydrocarbon molecules (Table 1) and more mobile in nanopore space, which may lead to a release of $\mathrm{CH}_{4}$ from tiny traps, additionally enhanced by pressure growth during $\mathrm{CO}_{2}$ injection (Huang et al., 2018). A much higher solubility of $\mathrm{CO}_{2}$ than $\mathrm{CH}_{4}$ in water enables hydrocarbon displacement in brine and increases the capacity of productive gas (Taggart, 2010). However, this mechanism is more important for conventional storage because brine in a shale reservoir is highly undesirable. From the technological point of view, injection of $\mathrm{CO}_{2}$ into depleted shale reservoirs may generate additional hydraulic fractures owing to rapid cooling of hot rock by $\mathrm{CO}_{2}$, producing thermal tension (Middleton et al., 2014). However, the higher viscosity of supercritical $\mathrm{CO}_{2}$ than $\mathrm{CH}_{4}$ limits $\mathrm{CO}_{2}$ flowback to production wells in response to a pressure drop, which is favourable for selective gas production and permanent $\mathrm{CO}_{2}$ storage. It is inferred from modeling that permanent $\mathrm{CO}_{2}$ trapping should enhance $\mathrm{CH}_{4}$ production from partially depleted reservoirs (Godec et al., 2014; Goodman et al., 2014; Schaef et al., 2014).

In practice, there are serious obstacles to $\mathrm{CO}_{2}$ storage implementation in shale reservoirs, because of technological limitations. This technology demands an acid-proof completion of gas production wells adjusted to future injection of $\mathrm{CO}_{2}$. The several-year gas production as a precondition for $\mathrm{CO}_{2}$ storage in shales (Schaef et al., 2014) implies that a significant cost of such completion has to precede hydrocarbon production and then expenses due to well reconstruction after the main gas production phase. On the other hand, additional costs of borehole completion and $\mathrm{CO}_{2}$ injection can be compensated, at least partially, by profits from additional gas production. Delayed return on investment costs is a barrier to the commercial take-up of this technology. Furthermore, there are technological reasons to perform the $\mathrm{CO}_{2}$ storage assessment before well completion is designed. In this paper, we show such a case of $\mathrm{CO}_{2}$ storage capacity assessment at a very early stage of shale gas exploration.

The relatively novel idea of $\mathrm{CO}_{2}$ storage in depleted shale gas reservoirs was first invented in the United States where unconventional gas production is most advanced (Nuttal et al., 2005; Rezaee, 2015; Ahmed and Meehan, 2016). So far, studies of $\mathrm{CO}_{2}$ storage capacity have used either static or dynamic approaches. Static models are based on the concept of gas-in-place assessment and assume the partial replacement of gas by $\mathrm{CO}_{2}$ (Goodman et al., 2014), regardless of physical processes and technological conditions accompanying $\mathrm{CO}_{2}$ injection, such as variable flow modes, pressure changes and the injection and production borehole pattern. A dynamic approach by contrast applies reservoir engineering models incorporating petrophysical parameters of shale matrix, the conductivity of open fractures, temperature and pressure conditions in the reservoir, and the properties of the fluids (Godec et al., 2013c; Edwards et al., 2015). Such models are calibrated by gas production data (Tao and Clarens, 2013). However, in this case, technological assumptions of the injection and production well array, such as location, number, length and separation between boreholes, have a major influence on the result of storage capacity calculation.

In our approach, based on data from a vertical exploration borehole (here named SeqWell) without hydraulic stimulation, we are able to apply only a static approach. However, we have attempted to extend this method by considering local geomechanical constraints and the potential of technological fractures to accumulate $\mathrm{CO}_{2}$. We have also aimed at discrimination of $\mathrm{CO}_{2}$ storage capacity building factors (storage categories) and assessment of their contribution to storage potential for each separate shale unit. The prospect for $\mathrm{CO}_{2}$ storage in the Pomeranian part of the Baltic Basin shale successions studied is dependent on gas production, which looks unlikely at the current stage of exploration. In spite of this, we have used this shale succession as a natural laboratory and provided an analysis applicable to any kind of shale prospect.

\section{GEOLOGICAL CONTEXT OF STORAGE CAPACITY ESTIMATION}

The study was performed on data obtained from a vertical borehole, called here SeqWell, located in the southern part of the Early Paleozoic Baltic Basin (Fig. 1). The shale successions in this basin developed from the Late Ordovician until the late Silurian in a distal part of the Caledonian foredeep basin developed as Baltica and Avalonia collided (Poprawa et al., 1999; Jaworowski, 2002).

Two main units of organic-rich shales (also called dark shale) are recognized within the Lower Paleozoic SeqWell section (Fig. 2): (1) The Sasino Formation (Sandbian/Upper Llanvirnian to lower Katian/Caradocian) comprises intercalations of black, often bituminous shales with tuffite, which results in a highly variable total organic carbon (TOC) content; (2) The Jantar Formation (Rhuddanian Stage of the Llandovery) consists of more homogeneous shale with a moderate TOC content (average 3.1\%). The lower part of the Pelplin Formation (Lower Wenlock) contains grey shale with minor intercalations of bentonite, and low TOC content $(\leq 1.5 \%)$. The two most pro- 


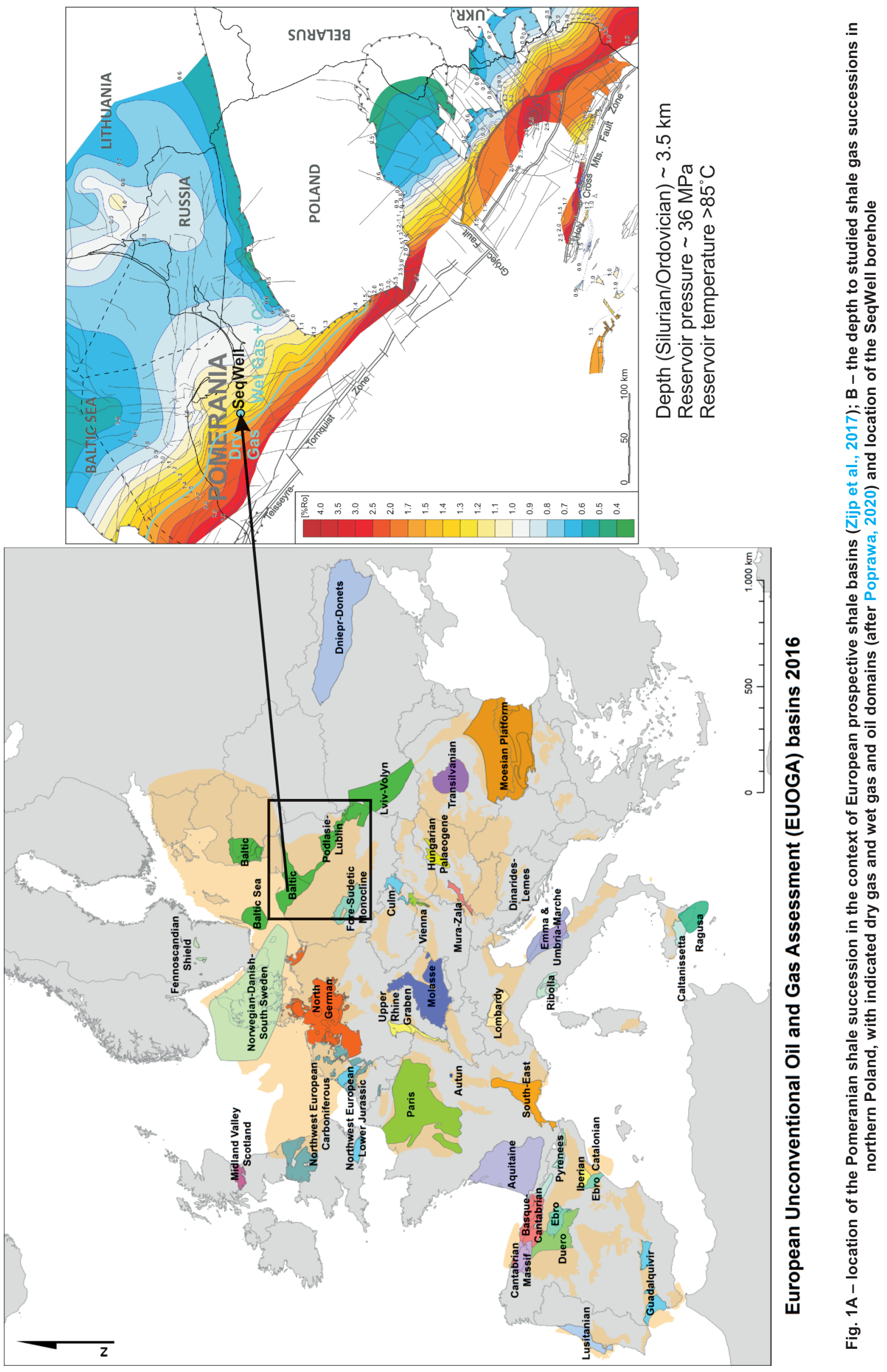



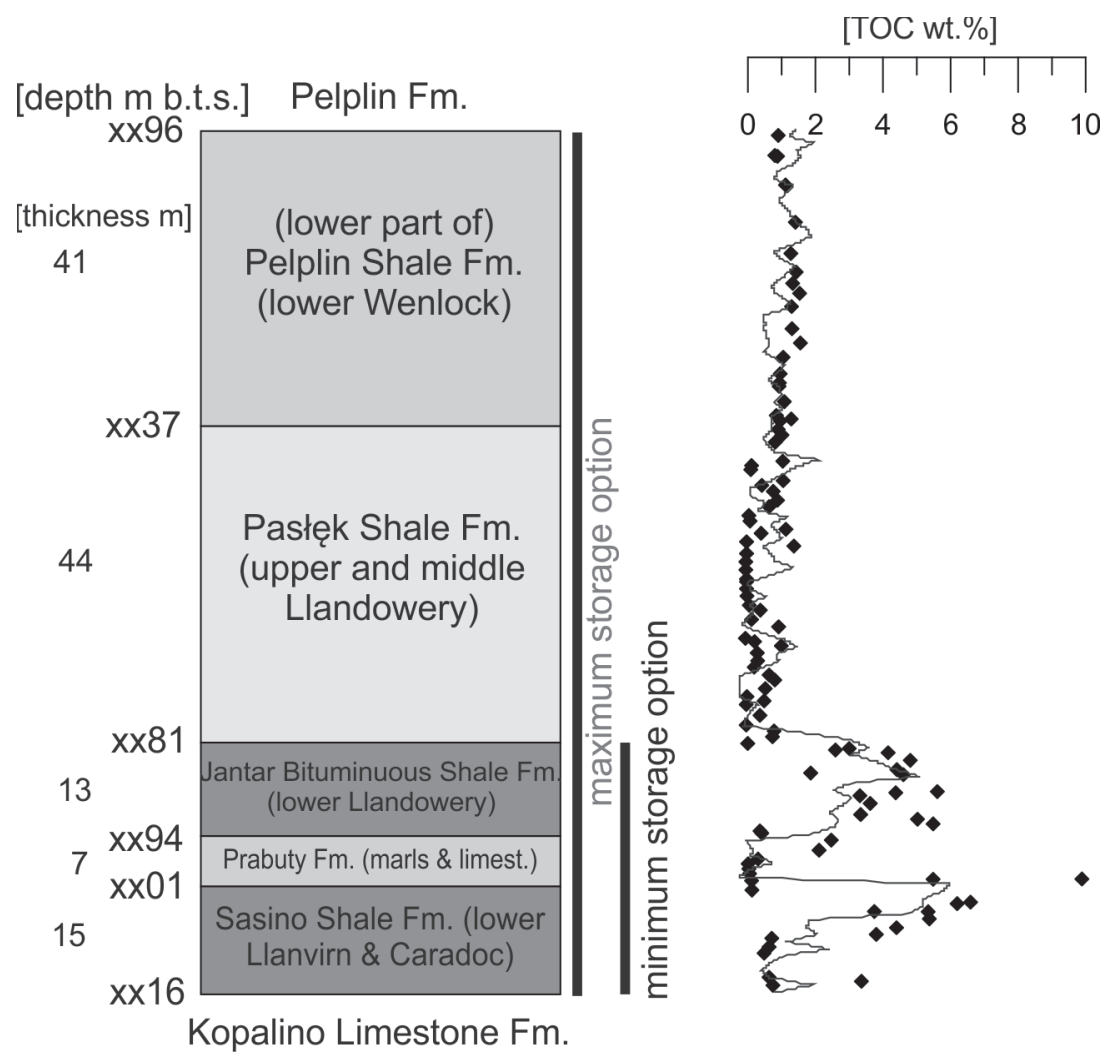

Fig. 2. The interval of lithostratigraphic column analysed in the SeqWell borehole, with local formation names used in the paper and TOC distribution after results of laboratory analyses (symbols) and wireline logging data interpretation (polyline; based on Chojnacki and Marzec, 2013; Leśniak, 2013; Miljanović and Jabłoński, 2013; Lutyński et al., 2017)

TOC-rich intervals are highlighted dark grey; TOC-poor intervals are pale grey; the Pelplin Fm. with a moderate content is marked (medium) grey; two options of storage range are shown, which are further applied in the storage capacity analysis

spective organic-rich shale formations (Sasino and Jantar) are separated by the Prabuty Formation that is dominated by marls and limestones with very low TOC content. In the upper part of that succession, the Jantar and Pelplin formations are separated by the Pasłęk Formation, poor in TOC. Such an organic-rich and -poor shale sandwich allows for comparison of the effectiveness of different storage categories depending on lithology. All the formations distinguished are laterally continuous across the basin, thus some observations based on the one SeqWell borehole study can be extrapolated with caution, bearing in mind the lateral changes in thickness and other shale gas reservoir parameters (Poprawa, 2020) important also for the $\mathrm{CO}_{2}$ storage capacity.

\section{DATA AND THEIR QUALITY}

For our study, we acquired industry-quality geological and geophysical data from the exploration SeqWell borehole. The dataset was provided by the Polish Oil and Gas Company, i.e. the operator of the hydrocarbon exploration concession under which the well was drilled (Chojnacki and Marzec, 2013; Leśniak, 2013; Miljanović and Jabłoński, 2013) and our industrial partner in the ShaleSeq and ShaleMech projects, which concerned aspects of $\mathrm{CO}_{2}$ storage and mechanical properties of the shale. Selection of this borehole was based on the following observations: (1) The SeqWell is located in the middle of the prospective part of the Pomeranian basin and proves typical basin-wide Ordovician and Silurian formations; (2) The depth of the interval studied is also typical of gas-bearing wells in Pomerania; (3) A continuous, >300 m long cored interval provides an ideal source of rock samples; (4) TOC is at the basin average level, as is the maturity of organic matter that promotes wet gas (or condensate) generation (Leśniak, 2013; Poprawa, 2020); (5) Industrial laboratory analyses and interpretations of modern borehole logs are numerous and accessible.

The SeqWell borehole wall was stable and the wire logs are of good quality. They comprise a standard set of tools that are usually used during hydrocarbon exploration (gamma ray + resistivity + neutron porosity + bulk density with photoelectric factor + sonic) supplemented with a geochemical log and dipole full wave sonic and electrical imagery. Such a set of measurements made it possible to perform analyses of mineral composition, porosity and saturation and combine them with geomechanical studies. The geophysical logging measurements were also used to evaluate TOC content within the rock formations analysed, which, in turn, was used to estimate the sorption capacity of the formations.

Petrophysical (and geochemical) interpretation was calibrated by a large number of laboratory analyses on numerous core samples and 81 sidewall cores, all provided by the Polish Oil and Gas Co., our industrial partner. To sum up, $311 \mathrm{~m}$ of core has been obtained from the Ordovician-Silurian strata. Based on those rock samples, 257 measurements of $\mathrm{He}$ 
picnometry, permeability and $\mathrm{Hg}$ porosimetry (MICP), while 95 nuclear magnetic resonance (NMR) porosity and pore distribution measurements were made. The organic matter and its products were examined using 226 RockEval measurements, with 26 vitrinite reflectance $\left(R_{o}\right)$ measurement, 69 degazations of the core and ${ }_{6}^{13} \mathrm{C}$ and ${ }_{1}^{2} \mathrm{H}$ isotope analyses of the gases; 36 gas desorption and $10 \mathrm{CH}_{4}$ sorption experiments were performed on the rock samples in the SeqWell (industrial data reports: Leśniak, 2013; Miljanović and Jabłoński, 2013). Additionally, $\mathrm{CO}_{2}$ and $\mathrm{CH}_{4}$ sorption experiments were performed on four samples from the SeqWell shales of relatively high TOC and varying by content of clay minerals, in the framework of the ShaleSeq project (Jarosiński and Wójcicki, 2016; Lutyński et al., 2017). We have also obtained access to the results of 48 geomechanical rock sample analyses with anisotropic elastic properties of shale rocks that were obtained within the framework of the ShaleMech project led by the Polish Oil and Gas Company and the Polish Geological Institute as the industrial and scientific leaders, respectively. To sum up, all laboratory measurements were taken from the industrial partner or from literature, but interpretation of necessary borehole logging, calibrated by results of laboratory analyses, was by us.

\section{FACTORS CONTROLLING STORAGE POTENTIAL}

In placing the $\mathrm{CO}_{2}$ storage categories in a wider context, the following observations are significant: (1) gas in shales appears either as free gas in inorganic and organic pore space and open fractures or as gas adsorbed on organic matter and, to a lesser extent, on clay minerals (Ambrose et al., 2010). Depending on the amount of organic matter and reservoir depth, the adsorbed gas accounts for $20-60 \%$ of the total gas (free + adsorbed) in shale (Kang et al., 2011; Heller and Zoback, 2014). (2) The pore (including micro-fracture) space distribution in shales is generally twofold. Free gas appears predominantly in relatively large pores $(>20 \mathrm{~nm}$ ), while adsorbed gas prevails in the smallest or small- to medium-sized (nano)pores - 2-5 nm and 5-20 nm, respectively (Kang et al., 2011). (3) Analysis of gas production curves indicates that after 10 years the share of free gas decreases significantly and a dominance of desorbed gas is observed (Godec, 2013b). $\mathrm{CO}_{2}$ storage in shales is based largely on $\mathrm{CO}_{2}-\mathrm{CH}_{4}$ replacement (Heller and Zoback, 2014), a process similar to enhanced $\mathrm{CH}_{4}$ recovery from a coal bed $\left(\mathrm{CO}_{2}\right.$-ECBMR - Shi et al., 2005). Taking the above into consideration, $\mathrm{CO}_{2}$ injection could be used as a secondary method to gas recovery (i.e. after 'regular' gas production) with a dual benefit of $\mathrm{CO}_{2}$ sequestration in the subsurface.

The $\mathrm{CO}_{2}$ storage potential and the $\mathrm{CH}_{4}$ accumulation and production in shales are controlled by a similar set of parameters: the TOC content, formation thickness, burial depth, reservoir temperature, and clay mineral content determining the brittleness, porosity and permeability.

\section{SHALE RESERVOIRS (SeqWell)}

In the SeqWell, the organic-rich shales of the Sasino and Jantar formations are $15 \mathrm{~m}$ and $13 \mathrm{~m}$ in thickness (gross; Leśniak, 2013; Fig. 2), respectively. However the net pay thickness of these formations is lower because the organic-rich shales (TOC $>2 \%$ ), have a combined thickness of prospective shale layers of barely $20 \mathrm{~m}$ (according to results of laboratory measurements - Leśniak, 2013 - and wireline logging data interpretation done by us; slightly less than half of the depth range of the Sasino Formation and almost the whole Jantar Formation are characterized by TOC $>2 \%$ ), which in general is the minimum required to define a productive shale gas reservoir (Ahmed and Meehan, 2016). The uppermost grey shale of the Pelplin Fm. has a much higher gross thickness reaching $126 \mathrm{~m}$ in total, of which only the lower $41 \mathrm{~m}$ thick interval (Fig. 2) is slightly enriched in TOC $>1 \%$ (according to results of laboratory measurements - Leśniak, 2013 - and wireline logging data interpretation done by us), although $<2 \%$, used as indicative for a shale gas reservoir.

Our storage capacity estimation is made for two options of depth intervals that may be available for production, depending on the vertical range of the hydraulically stimulated volume (Fig. 2). (1) The minimum storage interval, reaching $35 \mathrm{~m}$ in thickness, embraces the two most promising dark shale formations separated by a thin organic-poor shale formation. (2) The maximum storage interval with a thickness of up to $120 \mathrm{~m}$, including two organic-rich shale and grey shale intervals and the intervening organic-poor shale units. The theoretical storage interval is underlain by limestone of the Kopalino Fm., which due to a high lithological/mechanical contrast with the shales, creates an effective barrier for downward propagation of hydraulic fractures. Therefore, it defines the floor of our theoretical storage interval. From the top, the minimum and maximum storage intervals lack significant mechanical barriers. Thus, theoretically, an upward propagation of hydraulic fractures would be limited predominantly by technological factors related to stimulation. The results of hydraulic fracturing in the neighbouring Lubocino $2 \mathrm{H}$ borehole located $50 \mathrm{~km}$ north of the SeqWell (Gajek et al., 2018) show that the minimum $\mathrm{CO}_{2}$ storage thickness we have defined is comparable to the most frequently fractured interval, and the maximum $\mathrm{CO}_{2}$ storage thickness is slightly above the maximum vertical range of the stimulated reservoir volume (Gajek et al. 2018). However, the maximum $\mathrm{CO}_{2}$ storage thickness falls into a range of the most frequent height of hydraulic fractures in the shale basins in the USA, which ranges from $30 \mathrm{~m}$ up to $150 \mathrm{~m}$ for most treatments (Davis et al., 2012; Maxwell, 2011, Fisher and Warpinski, 2011), and would be probably obtainable in a massive hydraulic treatment in the study area.

\section{$\mathrm{CO}_{2}$ STORAGE MECHANISMS}

A lithological "sandwich" of gas-rich and gas-poor formations provides an opportunity to compare the potential for $\mathrm{CO}_{2}$ storage among various storage categories. In our approach, the $\mathrm{CO}_{2}$ storage capacity is represented by: (1) adsorption potential of organic matter, (2) open pore space, and (3) technologically open fracture space that has to be created before gas production. The last category is commonly not included in static $\mathrm{CO}_{2}$ storage capacity, because of uncertainty of fracture space evaluation and the fact that fractures develop largely at the expense of pore space. However, due to much easier access of $\mathrm{CO}_{2}$ to stimulated open fractures than to the tight pores in the rock matrix, the capacity of technological fractures might be counted separately. Bearing this in mind, we have proposed a method of including a separate category of storage potential in stimulated fractures.

In order to compare our results with some published case studies (e.g., Kalantari-Dahaghi, 2010; Edwards et al., 2015) we have assumed that the gas is produced by horizontal boreholes having $1 \mathrm{~km}$-long horizontal segments, and there are four such boreholes in each $1 \mathrm{~km}^{2}$ of reservoir (Fig. 3). Judging from the results of hydraulic stimulation in the Lubocino $2 \mathrm{H}$ borehole, located $60 \mathrm{~km}$ away from SeqWell (Gajek et al., 2018), $250 \mathrm{~m}$ of stimulated reservoir width from one horizontal well seems to be realistic for this part of the Baltic Basin. Also, the vertical range 


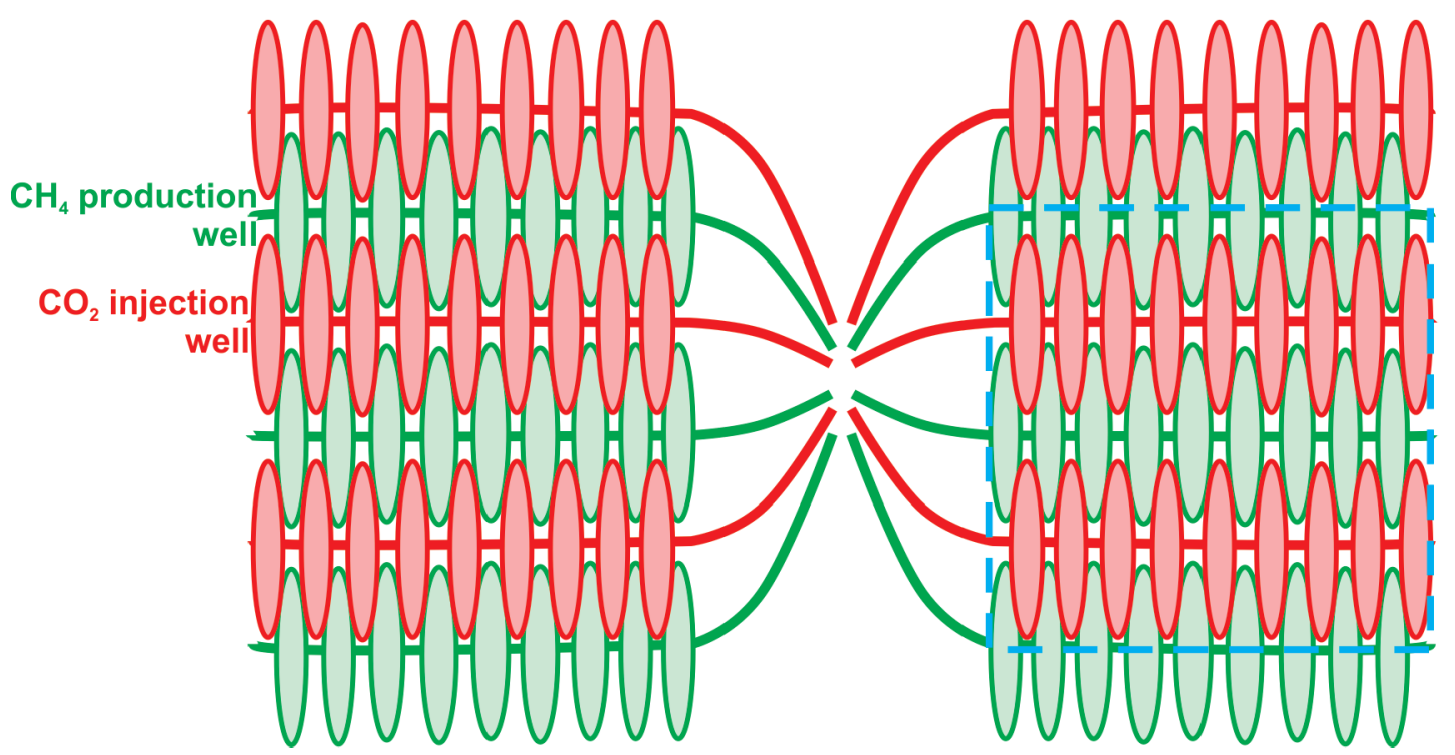

Fig. 3. Idealized pattern of $\mathrm{CO}_{2}$ injection and $\mathrm{CH}_{4}$ production wells, assumed for the storage scenario

It is assumed that in time the injection area (red) will replace progressively the production space; the blue dashed line shows $1 \mathrm{~km}^{2}$ of potential storage area

of the stimulated reservoir volume in the first stages is comparable to our minimum storage thickness, while in the last stages it is close to the assumed maximum storage thickness. For the storage scenario we assume that each second well is injector and that the entire stimulated volume, originally producing gas, is finally filled with $\mathrm{CO}_{2}$. Results of storage potential estimation for each storage category will be given in two ways: per average $1 \mathrm{~m}^{3}$ of each formation, to allow comparison of storage efficiency of different shale lithofacies; and per $1 \mathrm{~km}^{2}$ of each formation, to show the overall storage potential of the formations.

\section{RESERVOIR TEMPERATURE ASSESSMENT (SeqWell)}

One of the parameters controlling the capacity in all three storage categories is temperature. In the SeqWell only the bottom hole temperature (BHT) at a depth of 3759 m was measured, under unstable thermodynamic conditions (the measured values were $80 \div 90^{\circ} \mathrm{C}$ ). The correction relies on the local geothermal gradient $\left(2.3^{\circ} \mathrm{C} / 100 \mathrm{~m}\right)$ and the regional heat flow distribution gave a temperature of $94.2^{\circ} \mathrm{C}$ (Chojnacki and Marzec, 2013). Independent verification of the bottom hole temperature, based on the method described by Rider (1996), gave a similar result of $94.0^{\circ} \mathrm{C}$. In order to determine the temperature profile, we inferred analogy with the nearby Kościerzyna IG 1 borehole (located $\sim 25 \mathrm{~km}$ south of the SeqWell) that has more detailed measurements within the successions studied. There, the temperature profile was measured 14 days after mud circulation was stopped, under quasi-stable thermodynamic conditions (Modliński, 1982). The depth intervals of constant thermal gradient were then tracked in the Kościerzyna IG-1 borehole. Based on lithostratigraphic correlations between the two boreholes we found that a similar thermal gradient of $0.0212^{\circ} \mathrm{C} / \mathrm{m}$ can be applied for the shale successions investigated. Using the values of the geothermal gradients $G_{i}$ from the Kościerzyna IG 1 borehole and the corrected $B H T_{\text {corr }}$ for the SeqWell, we have calculated the synthetic temperature $\left(T_{S}\right)$ for any depth point $(h)$ of the depth interval analysed in the SeqWell using the following equation:

$$
T_{S}(h)=B H T_{\text {corr }}-\int_{h_{b}}^{h_{t}} G_{i} d h
$$

In the interval analysed (from the top of the lower Pelplin Formation to the base of the Sasino Formation (Fig. 2), the temperature ranges from 90.5 to $93.1^{\circ} \mathrm{C}$.

\section{METHODOLOGY AND RESULTS OF STORGE CAPACITY ASSESSMENT}

\section{SORPTION CAPACITY}

The crucial petrophysical property of gas-bearing shale is affinity of organic matter to adsorb $\mathrm{CO}_{2}$ at the pore surface. The typical organic carbon content TOC $>2 \%$ in shale gas reservoirs creates significant adsorption potential when a large volume of shale is considered (Godec, 2013b, c, 2014). Clay minerals also have ability to adsorb $\mathrm{CO}_{2}$, which may contribute to total storage capacity; however, adsorption onto clay mineral grains and organic matter is partly blocked by the presence of capillary and irreducible water (Heller and Zoback, 2014). The contribution of adsorption on dry organic nanopores is usually several times higher than adsorption on illite and kaolinite grains. A positive correlation of the gas sorption capacity with TOC is commonly observed (Tao and Clarens, 2013; Wei et al., 2013; Heller and Zoback, 2014). Because of the affinity of $\mathrm{CO}_{2}$ to adsorb onto organic matter and clay minerals is higher than for both $\mathrm{CH}_{4}$ and water, this agent is able to replace other fluids, liberate them and push them actively out of the system. Putting all these facts together in this study, we inferred that the $\mathrm{CO}_{2}$ sorption potential in shales is based mainly on $\mathrm{CO}_{2}-\mathrm{CH}_{4}$ replacement in pores in organic matter.

In the SeqWell borehole, most data regarding sorption refers to $\mathrm{CH}_{4}$, but not to $\mathrm{CO}_{2}$. For this reason, we have used the following procedure to determine the $\mathrm{CO}_{2}$ sorption. In the first step, we have checked the measured $\mathrm{CH}_{4}$ sorption capacity 
Parameters used in the calculation of sorption capacities within the SeqWell shale formations and the $\mathrm{CO}_{2}$ storage capacities and efficiencies

\begin{tabular}{|l|c|c|c|c|c|c|c|}
\hline Formation & $\begin{array}{c}\text { Formation } \\
\text { thickness } \\
{[\mathrm{m}]}\end{array}$ & $\begin{array}{c}\text { Rock bulk } \\
\text { density } \rho \\
{\left[\mathrm{t} / \mathrm{m}^{3}\right]}\end{array}$ & $\begin{array}{c}\text { TOC [wt.\%] } \\
\text { laboratory } \\
\text { (wireline } \\
\text { logging) }\end{array}$ & $\begin{array}{c}\mathrm{CH}_{4} \text { sorption } \\
\text { capacityy } \\
\mathrm{G}_{\mathrm{CH} 4}\left[\mathrm{~m}^{3} / \mathrm{t}\right]\end{array}$ & $\begin{array}{c}\left(\mathrm{CO}_{2} / \mathrm{CH}_{4}\right) \\
\text { ratio }\end{array}$ & $\begin{array}{c}\text { Capacity } \\
10 \% \text { of } S_{a \mathrm{aCO}} \\
{\left[\mathrm{t} / \mathrm{km}^{2}\right]}\end{array}$ & $\begin{array}{c}\text { Efficiency } \\
10 \% \text { of } S_{2} \mathrm{CO} 2 \\
{\left[\mathrm{~kg} / \mathrm{m}^{3}\right]}\end{array}$ \\
\hline Pelplin1 & 41 & 2.60 & $1.12(1.10)$ & 0.61 & 2.53 & 32525 & 0.79 \\
\hline Pasłęk & 44 & 2.57 & $0.46(0.68)$ & 0.47 & 2.50 & 26268 & 0.60 \\
\hline Jantar & 13 & 2.45 & $3.10(2.95)$ & 1.22 & 3.76 & 28884 & 2.22 \\
\hline Prabuty & 7 & 2.59 & $0.79(0.53)$ & 0.45 & 2.50 & 4032 & 0.58 \\
\hline Sasino & 15 & 2.48 & $3.26(2.50)$ & 1.12 & 2.60 & 21416 & 1.43 \\
\hline
\end{tabular}

and linked it to TOC values which were measured both in the laboratory and estimated from well logging curves (the latter being calibrated by results of laboratory measurements). Next, we took the results of parallel examination of $\mathrm{CH}_{4}$ and $\mathrm{CO}_{2}$ sorption capacity for similar samples (after Lutyński et al., 2017) and hence estimated the average values for replacement of $\mathrm{CH}_{4}$ with $\mathrm{CO}_{2}$ within particular formations (see Table 2). The number of laboratory experiments was not enough to determine the sorption capacity of the diverse shale profile under study, which concerns $\mathrm{CO}_{2}$ sorption in particular. In order to obtain the pattern of the $\mathrm{CO}_{2}$ sorption profile along the study interval we used the $\mathrm{CH}_{4}$ sorption profile together with the estimated ratio for replacement of $\mathrm{CH}_{4}$ with $\mathrm{CO}_{2}$ (Table 2).

The $\mathrm{CH}_{4}$ or $\mathrm{CO}_{2}$ sorption capacity of shale is defined as a function of the Langmuir isotherm parameters $\left(V_{S L}, P_{L}\right)$ and reservoir pressure $P$ (Ladage and Berner, 2012):

$$
G=\left(V_{S L} \times P\right) /\left(P_{L}+P\right)
$$

where: $V_{S L}$ - the Langmuir (sorption) volume, $P_{L}$ - the Langmuir pressure (the pressure at which half of the Langmuir volume can be adsorbed) and $P$ - the reservoir pressure.

The $V_{S L}$ defines a maximum potential of gas adsorption in the rock matrix at a given temperature. Since the $V_{S L}$ is correlated with the mass content of TOC in the rock matrix, the $V_{S L}$ profile for $\mathrm{CH}_{4}\left(V_{S L C H 4}\right)$ can be estimated using the TOC profile and an appropriate regression.

ASSESSMENT OF SORPTION CAPACITY FOR METHANE

The available sorption experiment data from the SeqWell consist of two sets of core samples. The first set (marked red in Fig. 4) has been retrieved from "fresh" cores - after natural gas desorption from core canisters in situ (measured in the field laboratory at the drilling site). This set of samples has also been used for the sorption experiments performed by Core Laboratories (Miljanović and Jabłoński, 2013). The second set of samples (marked blue and violet in Fig. 4) was retrieved one and a half years after the core was drilled, and then the sorption experiments have been performed (Lutyński et al., 2017). For simplicity, we will call these the first and the second sets of experiments.

Figure 4 shows the data collected in order to obtain a correlation between the Total Organic Carbon mass content (TOC) and the Langmuir Sorption Volume for $\mathrm{CH}_{4}\left(\mathrm{~V}_{\mathrm{SL} \mathrm{CH}}\right)$. For both sets of data, the TOC measurements were performed using a RockEval 6 apparatus.

The first set of analyses was performed at a temperature of $87^{\circ} \mathrm{C}$ and at a pressure range of up to $35 \mathrm{MPa}$ under conditions that are very close to those estimated for the storage interval in the SeqWell. The second set of experiments were performed at two temperatures $50^{\circ} \mathrm{C}$ (marked violet) and $80^{\circ} \mathrm{C}$ (marked blue) and at pressures of up to $15 \mathrm{MPa}$. There are only two values for $50^{\circ} \mathrm{C}$ and that does not yield enough data to analyse statistically. However, results of the second set of tests for both temperatures are similar, which may suggest that a $30^{\circ} \mathrm{C}$ temperature difference has a minor influence on the $\mathrm{CH}_{4}$ sorption capabilities at the given ranges of temperature and pressure, at least in the case of academic research experiments (i.e. the second set of analyses). The number of adsorption experiments on shale reservoirs indicates a significant decrease in sorption volume with increasing temperature within a given range. On the other hand, the result of the first set of sorption analyses shows that, for temperatures higher by $7^{\circ} \mathrm{C}$, the sorption is about twice as small as that obtained through academic research experiment. Such significant differences might not result from the temperature difference alone, as long as the $V_{S L}$ analyses are performed using similar methods. Therefore, we expect that the main difference between the red and blue regression lines (Fig. 4) of the $V_{S L}$ as a function of TOC is probably caused by the different sampling and sample preparation methods. Samples of the first set were milled and sieved to acquire grains 0.28-0.6 mm in size (Miljanović and Jabłoński, 2013), whereas samples of the second set were milled to obtain particles $<0.1 \mathrm{~mm}$ (Lutyński et al., 2017). Degasification (desorption) was performed before sorption in the first set of experiments. The other possible factor that can influence the results is possible organic matter alteration in the oxic, hypergenic environment of the core repository. The regression marked by a red line in Figure $4\left(T=87^{\circ} \mathrm{C}\right)$ seems to show the realistic potential of $\mathrm{CH}_{4}$ adsorption in a moderate period of time when gas infiltrates large and medium sized pores in shales (nanopores $>5 \mathrm{~nm}$; the exact time frame is not known precisely because of the lack of field or laboratory experiments). The regression marked by a blue line (Fig. 4) shows the likely maximum potential of $\mathrm{CH}_{4}$ adsorption over a long period of time when gas can infiltrate and diffuse into the smallest pores (nanopores $<5 \mathrm{~nm}$ ). This implies that the main factor might not be temperature but most likely the difference in sample preparation that affected coarser grains in the first case (red line) and finer grains in the second case (blue line).

For both datasets, the extrapolated regression lines (dotted lines in Fig. 4) intersect the y-coordinate axis above the 0 point. If the linear regression holds, this points to remnant sorption in a hypothetical situation where the samples have been deprived of all organic matter. This suggests that organic matter is not the only factor controlling the sorption in the study samples. Factors controlling the sorption potential have been thoroughly discussed by Lutyński et al. (2017) who came to the conclusion 


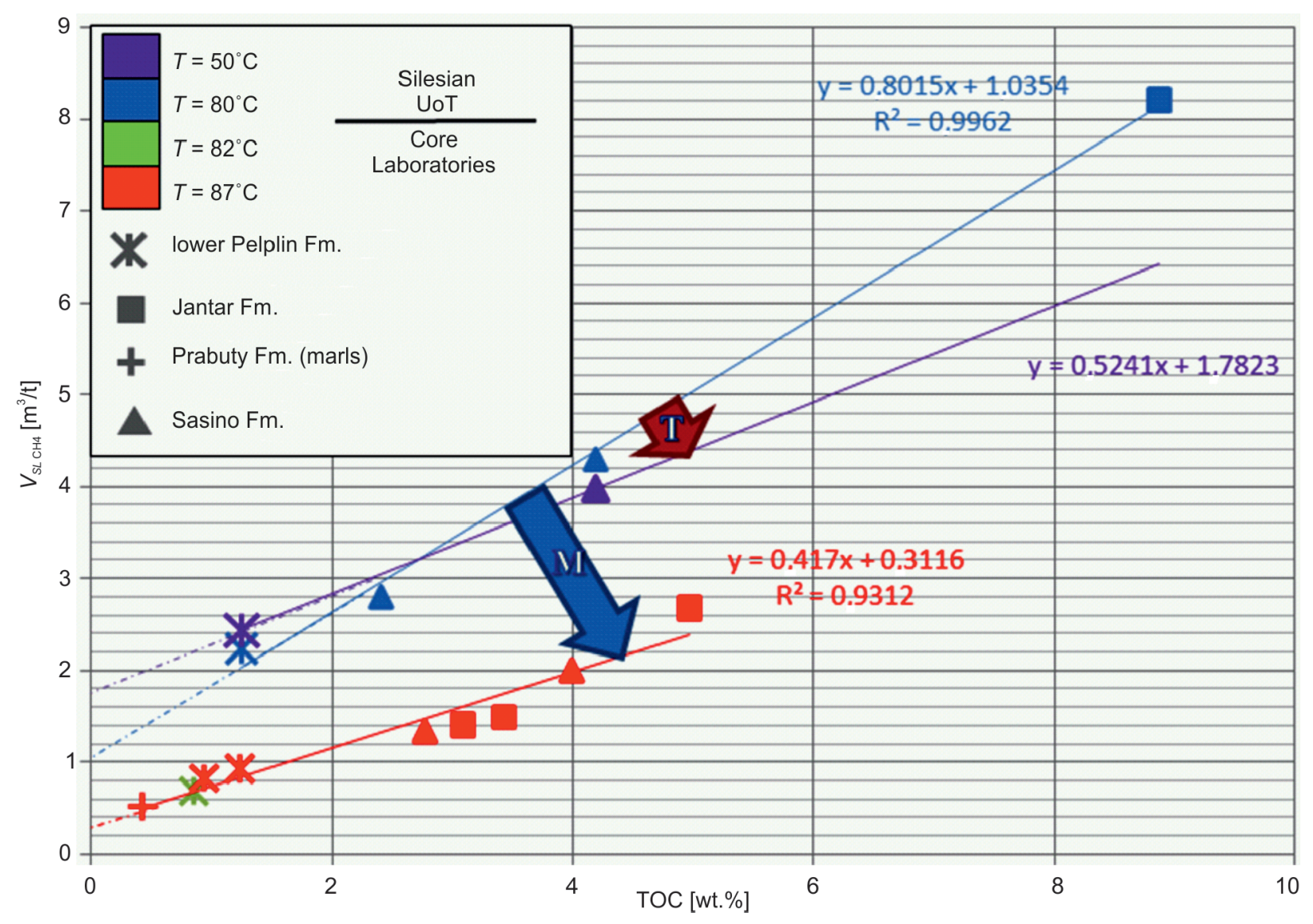

Fig. 4. Relationship between the $\mathrm{CH}_{4}$ sorption volume $V_{S L}$ and total organic carbon mass content TOC for different temperatures (expressed by the colours) and lithostratigraphic units (expressed by the linework)

The "M" arrow shows the major impact of the method of sample preparation (sorption experiments were performed at similar temperatures), whereas the "T" arrow shows that the temperature impact on the measurements is minor (both regression lines are based on measurements performed by the same laboratory)

that it depends on the Total Specific Surface Area (TSSA) of the rocks analysed and on the characteristics of these inner surfaces, mainly as regards their hydrophobic/hydrophilic properties.

\section{APPROACH TO THE SORPTION CAPACITY FOR CARBON DIOXIDE}

The results of the first set of sorption experiments addressed only the $\mathrm{CH}_{4}$ sorption capacity (Miljanović and Jabłoński, 2013), while in the research experiments, sorption capacities for both $\mathrm{CH}_{4}$ and $\mathrm{CO}_{2}$ were determined (Jarosiński and Wójcicki, 2016; Lutyński et al., 2017). The academic research experiments showed that the $\mathrm{CO}_{2}$ absorption in prospective shale formations of the SeqWell is $\sim 2.5-3.8$ times higher than in the case of $\mathrm{CH}_{4}$ in shale samples of the same TOC content and lithology, and measured at the same temperature $\left(T=80^{\circ} \mathrm{C}\right)$. That means that, under standard laboratory conditions, $2.5-3.8 \mathrm{~m}^{3}$ of $\mathrm{CO}_{2}$ can be adsorbed in place of $1 \mathrm{~m}^{3}$ of $\mathrm{CH}_{4}$. Similar experiments for productive shales in the USA indicate an absorption capacity ratio $\mathrm{CO}_{2} / \mathrm{CH}_{4}$ in the range of 2-6 (Kang et al., 2011; Tao and Clarens, 2013; Heller and Zoback, 2014), depending on the amount of organic matter and clay minerals in the shales, the lower range being generally consistent with our result.

Since then, to calculate the sorption capacity for $\mathrm{CO}_{2}$, based on [2] and the sorption capacity ratios, we applied the following formula:

$$
G=r \times\left(V_{S L C H} \times P\right) /\left(P_{L_{C H}}+P\right)
$$

where: $V_{S L C H 4}$ - the Langmuir (sorption) volume, averaged within the formation, obtained from regression of the first set of data (Miljanović and Jabłoński, 2013; Fig. 4; TOC profile obtained from interpretation of wireline logs done by us, calibrated with results of RockEval TOC laboratory measurements), $P_{L}-$ (average) Langmuir pressure measured on shale samples within the formation, $P$ - reservoir pressure, and $r-\mathrm{CO}_{2}$ to $\mathrm{CH}_{4}$ sorption capacity ratio after academic research tests (Jarosiński and Wójcicki, 2016; Lutyński et al., 2017)

As noted above, the sorption capacity mechanism prevails in the smallest and, to some extent, medium-sized nanopores, and thus in order to assess the respective storage capacity contribution, the available data pertaining to the nanopores in question have been analysed. Figure 5 shows the pore space distribution within the maximum storage thickness range $(120 \mathrm{~m})$. The dynamic porosity data (percentages of the total dynamic porosity) obtained from mercury injection capillary pressure porosimeter measurements (MICP) on shale rock samples have been used for the following intervals of diameter of pore channels: $3-10 \mathrm{~nm}, 10-100 \mathrm{~nm}, 100-1000 \mathrm{~nm}$ and over 1000 nm (Leśniak, 2013; Fig. 5). According to studies on shale samples from US plays (Ambrose et al., 2010; Kang et al., 2011) in relatively large nanopores and channels (diameter $>50 \mathrm{~nm}$ ), free gas dominates and in smaller nanopores and 
channels (diameter $<50 \mathrm{~nm}$, though pores and channels $<3 \mathrm{~nm}$ cannot be accessed because of the MICP method constraints) adsorbed gas dominates. In the intermediate interval of pore diameter $(3-50 \mathrm{~nm})$ both free and adsorbed gas can occur in comparable percentages. These measurements (Fig. 5) did not provide information on the share of pore channels $<\sim 3 \mathrm{~nm}$, but according to results from US plays (e.g., Kang et al., 2011) this share is most likely higher than those $>50 \mathrm{~nm}$.

RESULTS OF $\mathrm{CO}_{2}$ SORPTION CAPACITY ASSESSMENT

For our calculations, we used a simple formula for $\mathrm{CO}_{2}$ storage capacity related to the sorption potential of organic matter $S_{a}$ :

$$
S_{\mathrm{aCO} 2}=V \times \rho \times G_{\mathrm{CH} 4} \times r \times \rho S_{\mathrm{CO} 2}
$$

where: $V$ - reservoir rock volume, $\rho$ - bulk density of shale, $G_{C H 4}-$ gas sorption capacity of shale (see formulae [2] and [3]), $r-\mathrm{CO}_{2}$ to $\mathrm{CH}_{4}$ sorption capacity ratio, and $\rho s_{\mathrm{CO} 2}-\mathrm{CO}_{2}$ density in standard conditions (Table 1).

Determination of the reservoir rock volume was based on assessment of the thickness of shale reservoirs. According to the best practice based on experience of US shale plays (Andrews, 2013; EIA, 2013) the thickness of productive shale reservoirs is determined using available data on TOC $(>2 \%)$, porosity filled with hydrocarbons (at least $2 \%$ ), gas content $\left(>2.8 \mathrm{~m}^{3} / \mathrm{t}\right)$, and silicate+carbonate $(>65 \%)$ and clay $(<35 \%)$ content. Values of these parameters are assessed using results of laboratory analyses of rock samples and interpretation of well logging data (in our case obtained from literature, including information provided by the industrial partner, only the TOC profile was calculated in this study using wireline logs). However, the entire succession studied does not meet all these textbook criteria. For example, the Jantar and Sasino formations do meet the TOC and porosity criteria but not fully the remaining ones (i.e. only parts of these formations are characterized by sufficiently high gas and/or silicate+carbonate content; Leśniak, 2013). For this study, two options of storage arrangement were considered: (1) a maximum thickness comprising two organic-rich and one grey shale intervals separated by two organic-poor shale formations that attain $120 \mathrm{~m}$, and (2) a minimum thickness comprising two organic-rich shale intervals separated by an organic-poor shale formation 35 m thick.

The bulk density of the shale was assessed using results of laboratory analyses of rock samples (Leśniak, 2013). Langmuir isotherm parameters $\left(V_{S L}, P_{L}\right)$, were assessed using results of laboratory measurements of rock samples. In the case of Langmuir volume, this parameter was additionally approximated using TOC data obtained from interpretation of wireline logs (done by us; see Fig. 2), calibrated by published results of laboratory analyses of rock samples (TOC and $V_{S L}$ ). For the purpose of this study we have adopted the ratios of $\mathrm{CO}_{2} / \mathrm{CH}_{4}$ sorption capacities from results of laboratory analyses at a temperature of $80^{\circ} \mathrm{C}$ (Jarosiński and Wójcicki, 2016; Lutyński et al., 2017). Results of sorption capacity analyses for both gases were available for one sample of the Pelplin Fm., two of the Jantar Fm. and one of the Sasino Fm. For the organic-poor Pasłęk and Prabuty formations, no suitable data were available; therefore the $\mathrm{CO}_{2}$ to $\mathrm{CH}_{4}$ sorption capacity ratio was assumed to be close to the lower limit of the parameter range (after Kang et al., 2011; Tao and Clarens, 2013; Heller and Zoback, 2014).

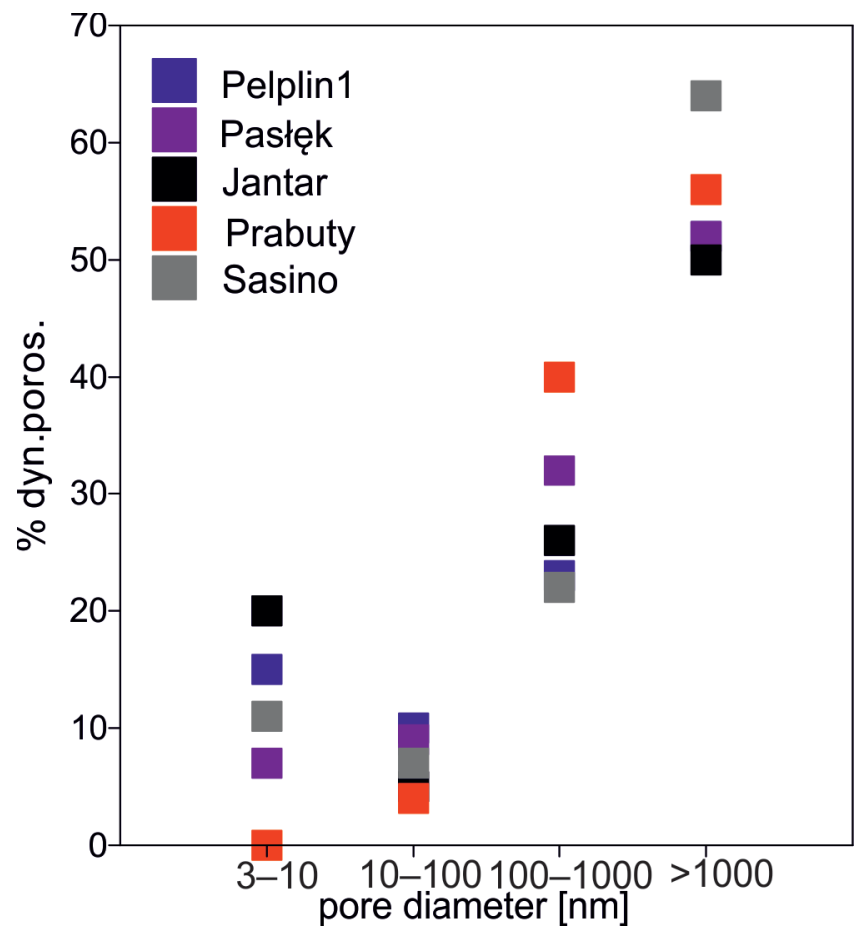

Fig. 5. Pore space distribution in the SeqWell shale sequence for several intervals of diameters of pore channel (based on the first set of data on SeqWell provided by POGC - Leśniak, 2013 results of mercury porosimetry)

To allow comparison of storage volumes with results obtained by other researchers and considering the low permeability of our shales we accepted the common assumption for the USA shale basins that the $\mathrm{CO}_{2}$ will be able to reach effectively only $10 \%$ of theoretical total sorption volume (after Godec, 2013b, c).

The mean or approximate values of the parameters pertaining to the sorption potential in shales are shown in Table 2. For reference, the mean TOC content from the laboratory tests and from the wireline logs calibrated by them are shown. One measured or assumed average value of the parameter was taken for each formation separately. The storage capacity $\left(S_{a c 02}\right)$ given in tonnes per $1 \mathrm{~km}^{2}$ of each formation is finally reduced to $10 \%$ of the total calculated $\mathrm{CO}_{2}$ capacity. The storage efficiency, which expresses the ability to store $\mathrm{CO}_{2}$, is given for the volume unit of $1 \mathrm{~m}^{3}$ for each formation.

Our estimates indicate that the Jantar Fm. shows the highest $\mathrm{CO}_{2}$ sorption storage efficiency. The Sasino Fm. has lower sorption efficiency probably due to its lithological heterogeneity, and its TOC obtained from laboratory measurements is relatively high because mostly organic-rich shales were sampled (Leśniak, 2013). $\mathrm{CO}_{2} / \mathrm{CH}_{4}$ sorption ratios for these formations differ significantly (according to results of Lutyński et al., 2017), based on analyses on two rock samples of the Jantar Fm. and of one rock sample of the Sasino Fm.). However, both formations have 3-4 times higher sorption efficiency than the organic-poor shale formations. The intermediate Pelplin Fm. has a sorption efficiency slightly better than organic-poor shales, but due to its large thickness its capacity is slightly greater than that of the best Jantar Fm. For the same reason, the thick organic-poor Pasłęk Fm. also has a capacity comparable to the organic-rich shale formations. 
PORE SPACE CAPACITY

APPROACHES TO ASSESSMENT OF PORE SPACE CAPACITY

Information on porosity values is available from interpretation of well logs calibrated with laboratory measurements provided by the industrial partner (Chojnacki and Marzec, 2013; Leśniak, 2013). Helium pycnometer measurements were performed on intact and powdered or granulated rock samples in order to assess the total or open helium porosity, respectively (Leśniak, 2013). We also possessed the results of dynamic porosity measurements made using the mercury injection capillary pressure (MICP) method available (Leśniak, 2013). Capillary pressure values were selected which correspond to the following diameters of pore channels: $3-10 \mathrm{~nm}, 10-100 \mathrm{~nm}$, 100-1000 nm, and over 1000 nm (see also Fig. 5). As a result, 117 helium pycnometer and MICP measurements on borehole core samples were completed for the maximum storage interval. The industrial partner provided also the NMR porosity measurements (Leśniak, 2013) that estimate the capillary and irreducible water saturation of the pore space, including inter-layer spacing of clay minerals. The question is whether the contribution due to irreducible water saturation in the NMR method might include gas adsorbed in small pores, while the NMR method is susceptible to hydrogen but not (only) to water. In our analysis, we have not taken into account the water content, assuming that the water bound in interlayer space in clay minerals is not counted as pore space accessible for $\mathrm{CO}_{2}$. Hence, the NMR porosity data were not used in our study.

The total helium porosity values obtained are relatively stable and fit well to the total porosity curve interpreted from well logging data. The total and open helium porosity values do not differ significantly, i.e. the total porosity is slightly higher than the open porosity. These measurements are based on the use of powdered or granulated samples (Darłak et al., 2011; Leśniak, 2013) and the effectiveness of fluid extraction and drying of samples depends on granulation sizes. The fact that both porosity values do not differ significantly might be explained, to some extent, by the impact of measured sample preparation or, more likely, the relatively small size of helium atoms (in comparison with, for example, methane molecules) which makes it possible to penetrate pore channels "closed" to other gases or fluids, and both measurement techniques do not detect pores occupied by clay-bound water (Yuan and Rezae, 2019). However, only open porosity data were used in this study because these data are linked to potentially productive gas accumulations in shales. It was systematically observed that both open and total helium porosity values were $2-4$ times higher than the values of dynamic porosity obtained from MICP porosimetry. The discrepancy is explained in that the porosity measured by a helium pycnometer is linked both to very small nanopores and pore channels and to larger ones (Leśniak, 2013). MICP porosimetry does not detect the very small nanopores and pore channels $(<3 \mathrm{~nm})$ which comprise a significant proportion of total porosity of the lower Silurian and Upper Ordovician shales in the Pomeranian part of the Baltic basin (Krzyżak et al., 2020). Based on nitrogen adsorption-desorption isotherms, Krzyżak et al. (2020) argued that this is due to the peak of derivative distribution of pore volume with respect to a pore diameter being at $\sim 2 \mathrm{~nm}$. Mercury injection is not always a satisfactory approximation of $\mathrm{CH}_{4}$ or $\mathrm{CO}_{2}$ motion in nanopores under shale conditions, especially in vuggy, poorly consolidated or high permeability shales (Krzyżak et al., 2020), but the shales in question (SeqWell borehole; Leśniak, 2013) do not belong to these categories.

The $\mathrm{CO}_{2}$ storage capacity due to open pore space contribution was estimated firstly by using results of laboratory mea- surements of MICP porosity for relatively large pores. That means the pores are sufficiently large to retain more free gas than adsorbed gas. The lower threshold for free gas prevalence in pores of US shales is estimated to be between 2 and $50 \mathrm{~nm}$ (Kang et al., 2011). Because of the available results of laboratory measurements in the SeqWell borehole (Fig. 5) we assumed a threshold of $10-100 \mathrm{~nm}$ and presumed that the total open space of pores $>100 \mathrm{~nm}$ can be filled by free gas (apart from formation water). Such an assumption was justified by data on US shales where, according to Ambrose et al. (2010), $\sim 96 \%$ of the total open space of pores $>100 \mathrm{~nm}$ can be filled with free gas or supercritical $\mathrm{CO}_{2}$. According to results of MICP measurements shown in Figure 5, the share of $10-100 \mathrm{~nm}$ pores is the smallest of all ranges of pores in the shale. These pores might retain more or less comparable percentages of free and adsorbed gas. The share of $3-10 \mathrm{~nm}$ pores is slightly higher (than of 10-100 nm pores) and they likely do not include a significant volume of free gas, because adsorbed gas prevails here. The pores $<3 \mathrm{~nm}$ do not appear in Figure 5 because they cannot be detected by MICP porosimetry, but their share in the porosity of the shales is most likely quite high (Krzyżak et al., 2020) and might be at least comparable to pores $>100 \mathrm{~nm}$ (Kang et al., 2011). Overall, the omitted share of free gas in $10-100 \mathrm{~nm}$ pores might be compensated by a slight overestimation of the share of free gas in pores $>100 \mathrm{~nm}$.

RESULTS OF PORE SPACE CAPACITY ASSESSMENT

As no unequivocal approach to estimate the pore space capacity for $\mathrm{CO}_{2}$ storage exists, the pore space volumes obtained from the MIPS measurements for pores $>100 \mathrm{~nm}$ (dynamic porosity) have been considered (Table 3 ) as the lower limit of available open pore space, and the values obtained from helium pycnometer analyses (open porosity) as the upper limit. The $\mathrm{CO}_{2}$ storage capacities based on these parameters are denoted in Table 3 as minimum and maximum, respectively. The porosity measured by a helium pycnometer is linked both to very small nanopores (or pore channels) and to larger ones, but the values obtained from MICP porosimetry refer likely to larger nanopores only. Hence, for further consideration it was accepted that the minimum pore volume option makes a better approximation of open pore space capacities available for $\mathrm{CO}_{2}$ storage than do the values obtained from helium porosimetry. The comparison between porosity options (Table 3 ) indicate that the option maximum is $3-4$ times higher than the minimum, so the uncertainty in the porosity model adopted is the major source of uncertainty in evaluating the $\mathrm{CO}_{2}$ storage capacity in the pore spaces.

Temperature and pressure determine the density of supercritical $\mathrm{CO}_{2}$, and thus the pore storage capacity. The temperature was taken from the previous estimations in the range of 90.5-93. $1^{\circ} \mathrm{C}$. The pore pressure was not measured directly in the SeqWell borehole; however, due to a lack of information concerning overpressure in this part of the basin we accepted the hydrostatic formation pressure for the entire depth interval. For these parameters, the density of $\mathrm{CO}_{2}$ was calculated using an online $\mathrm{CO}_{2}$ calculator at the Peace software website (http://www.peacesoftware.de/einigewerte/co2_e.html). Because the calculated density values within the depth and temperature intervals studied vary in the narrow range of $0.7616 \div 0.7617 \mathrm{~kg} / \mathrm{m}^{3}$, this was approximated to $0.762 \mathrm{~kg} / \mathrm{m}^{3}$.

The $\mathrm{CO}_{2}$ capacity values were averaged within the shale formations analysed (Table 3). Due to the low permeability of shale the common assumption for static modeling of $\mathrm{CO}_{2}$ capacity in the USA shale basins was adopted, that the supercriti- 
Parameters used in calculation of the open pore space capacities and storage efficiencies for the SeqWell (porosity data after Leśniak, 2013)

\begin{tabular}{|c|c|c|c|c|c|c|c|c|}
\hline Formation & $\begin{array}{c}\text { Thickness } \\
{[\mathrm{m}]}\end{array}$ & $\begin{array}{l}\text { Dynamic } \\
\text { porosity } \\
(\mathrm{MICP}) \\
{[\%] \text { (min) }}\end{array}$ & $\begin{array}{c}\text { Pores }>100 \mathrm{~nm} \\
{[\% \text { of } \mathrm{MICP}]} \\
(\mathrm{min})\end{array}$ & $\begin{array}{l}\text { Open }(\mathrm{He}) \\
\text { porosity [\%] } \\
\quad(\max )\end{array}$ & $\begin{array}{c}\text { Capacity } \\
10 \% \text { of min } \\
{\left[\mathrm{t} / \mathrm{km}^{2}\right]}\end{array}$ & $\begin{array}{c}\text { Capacity } \\
10 \% \text { of } \\
\max \left[\mathrm{t} / \mathrm{km}^{2}\right]\end{array}$ & $\begin{array}{c}\text { Efficiency } \\
10 \% \text { of min } \\
{\left[\mathrm{kg} / \mathrm{m}^{3}\right]}\end{array}$ & $\begin{array}{c}\text { Efficiency } \\
10 \% \text { of max } \\
{\left[\mathrm{kg} / \mathrm{m}^{3}\right]}\end{array}$ \\
\hline Pelplin1 & 41 & 2.65 & 75.2 & 5.88 & 6988 & 18370 & 0.17 & 0.45 \\
\hline Pasłęk & 44 & 2.48 & 84.4 & 7.50 & 6269 & 25146 & 0.14 & 0.57 \\
\hline Jantar & 13 & 3.41 & 75.4 & 9.06 & 3239 & 8975 & 0.25 & 0.69 \\
\hline Prabuty & 7 & 2.35 & 95.9 & 6.83 & 1068 & 3643 & 0.15 & 0.52 \\
\hline Sasino & 15 & 2.13 & 85.2 & 8.31 & 2325 & 9498 & 0.16 & 0.63 \\
\hline
\end{tabular}

cal $\mathrm{CO}_{2}$ will be able to reach effectively only $10 \%$ of theoretically available open pore space volume (after Godec, 2013b, c). Hence, the values of $\mathrm{CO}_{2}$ storage capacities and efficiencies are representative for this fraction of either dynamic or open porosity volumes (minimum and maximum) within $1 \mathrm{~km}^{2}$ of shale distribution.

Our analyses indicate that the results of the storage capacity assessment in pore space depend on the porosity model. The open pore space storage capacities and efficiencies for the maximum (max) model are $\sim 3$ times higher than for the minimum (min) porosity model.

We have chosen the ( $\mathrm{min}$ ) model, as a better approximation of open pore space capacities available for $\mathrm{CO}_{2}$ storage, because this model refers to larger pores where free gas prevails decisively over adsorbed gas. POGC data included in Table 3 (MICP vs He-porosity) suggest the percentage of larger pores $(>100 \mathrm{~nm}$ ) might be 3-4 times lower than that of the smallest nanopores $(<3 \mathrm{~nm})$. Krzyżak et al. (2020) also showed that the nanopore size variation in the Baltic Basin shales is highest around $2 \mathrm{~nm}$ and Yuan and Rezae (2019) point out that the share of pores $>100 \mathrm{~nm}$ is negligible in some shale plays worldwide, and in some it is not, but is still smaller than share of smallest nanopores. SeqWell shales are apparently characterized by a low share of larger pores, considered for the $\mathrm{CO}_{2}$ storage mechanism in open pore spaces. The (max) model, as noted above, refers predominantly to small nanopores where adsorbed gas prevails, so in order to avoid accounting for the same porosities twice this option is discarded in further analyses.

Despite the pore model option, the $\mathrm{CO}_{2}$ storage capacity and efficiency in pores is higher in organic-rich shales with a dominance of the Jantar Fm. over the Sasino Fm. in most cases. The reason seems to be obvious - an increase of pore space in organic matter due to gas generation. However, in this case, the difference in storage efficiency between organic-rich and organic-poor shales is not very significant; a ratio of $3 / 2$ is the highest. Therefore, the result of storage capacity in pore space depends mostly on the formation thickness.

\section{OPEN FRACTURE CAPACITY}

\section{APPROACHES TO OPEN FRACTURE CAPACITY ASSESSMENT}

Open fractures in shales may have a purely tectonic origin or be a product of hydraulic fracturing stimulation in order to increase reservoir permeability. There is lack of direct in situ measurements of fracture aperture in shale reservoirs; however, the maximum estimate is in the range of micrometres (Gale et al., 2014). Therefore, even in the case of a dense tectonic fracture system (2-10 fractures per metre of borehole profile) as in the
SeqWell borehole (Bobek and Jarosiński, submitted), their integrated open aperture can be estimated in the order of $10^{-5}$ (dimensionless measure of extension). This is negligible in comparison with porosity of the order of $5 \%$. However, the aperture of fractures increases significantly as a result of hydraulic fracturing. The open fracture space is maintained by proppant or asperities created by the roughness of fracture walls mutually displaced. A simple comparison of volume of fracking fluid remaining in a reservoir after flowback, which is estimated at $60-90 \%$ of injected fluid, with a $5-10 \%$ volume of proppant (Economides and Nolte, 2000; Davies et al., 2012), indicates that only a minor fraction of stimulated open fractures is maintained by proppant. The rest have to be bridged by asperities of natural fractures. In the production phase, the fracking fluid is successively removed out of the reservoir together with gas, leaving space for the future storage of $\mathrm{CO}_{2}$.

The orientation of open cracks is controlled by the present-day tectonic stress direction in the way that apertures of stimulated fractures expand in the direction of minimum principal stress $\left(S_{3}\right)$. In the case of the strike-slip stress regime estimated for the Pomeranian shale (Jarosiński, 2006), the minimum principal stress is horizontal $\left(S_{3}=S_{\text {hmin }}\right)$, which favours the stimulation of vertical fractures. However, the opening of vertical fractures results in $S_{\text {hmin }}$ growth caused by a stress shadowing effect (e.g., Taghichian et al., 2014), which is a function of horizontal strain (aperture expansion), elastic parameters, and fracture geometry. For the purpose of our $\mathrm{CO}_{2}$ storage assessment, we adopt a simplified, one-dimensional model of uniform horizontal expansion of fractures within the lithostratigraphic formations. Such an approach fits the scenario in which a large part of Pomerania is regularly covered by stimulated horizontal boreholes, and that there is no mechanical interaction between the formations. The assumption of mechanical decoupling between formations results in artificial layering of open fracture capacity, however it shows what the contribution of individual formations is in creating the overall open fracture space.

In the strike-slip stress regime probably governing the geomechanics of the Baltic Basin, the vertical stress $\left(S_{V}\right)$ is the intermediate principal stress $\left(S_{V}=S_{2}\right)$. It was computed from the density curve for a mid-formation depth of each formation. The $S_{V}$, generated by the gravitational load of overburden, is assumed to stay constant during hydraulic stimulation. When, due to the stress shadowing effect, the $S_{h \min }$ becomes higher than $S_{V}$, horizontal fractures start to open. Because stimulation of horizontal fractures is a very undesirable effect, the stimulation should then be ceased. Therefore, the larger is the difference between stresses $\left(S_{V}-S_{h m i n}\right)$, the higher is the potential for vertical fractures to be opened. To calculate this potential, we have applied an anisotropic (Vertical Transverse Isotropic) geomechanical model of the reservoir in which vertical elastic 
parameters differ significantly from horizontal ones. For the shale formations analysed, constant values of vertical and horizontal Young moduli $\left(E_{V}\right.$ and $\left.E_{H}\right)$ and Poisson's ratios $\left(V_{V}\right.$ and $v_{H}$ ) were calculated for the formations as mean values from mechanical laboratory tests (Table 4). For this purpose, the results of 48 mechanical tests equally shared between horizontal and vertical samples were used.

Due to lack of indicators of pore fluid overpressure, we assumed a mean hydrostatic pressure for each formation. Good stress indicators are lacking in the SeqWell borehole, as hydraulic fracturing tests have not been performed, and stress-induced borehole breakouts are present only above the section analysed, where the required mechanical data have not been collected (Wojtowicz et al., 2019). Therefore, we had to adopt some data from the neighbouring $\mathrm{L}-2 \mathrm{H}$ borehole, in which $S_{h \text { min }}$ was determined from hydraulic fracturing tests that preceded the main hydraulic treatments. The calculation of initial tectonic stress $S_{h \text { min, }}$ based on the pure elastic approach (Higgins et al., 2008), is as follows:

$$
S_{h \min }=\frac{E_{h}}{E_{v}} \frac{v_{v}}{1-v_{h}}\left(S_{v}-\alpha P_{r}\right)+\alpha P_{r}+\frac{E_{h}}{1-v_{h}^{2}} \varepsilon_{h \min }+\frac{v_{h} E_{h}}{1-v_{h}^{2}} \varepsilon_{H \max }
$$

where: the VTI mechanical parameters are given in Table $4, \alpha$ - the Biot coefficient adopted from literature (Stadtmuller et al., 2018), and $\varepsilon_{h \min }$ and $\varepsilon_{H \max }$ - tectonic horizontal strains in the direction of respective principal horizontal stresses. Their values were taken from the $\mathrm{L}-2 \mathrm{H}$ borehole located $50 \mathrm{~km}$ from the SeqWell. We think that keeping a constant tectonic strain over a distance of tens of kilometres in continuous lithostratigraphic formations is a realistic assumption in the part of the East European Craton analysed, that has a simple tectonic structure and lacks large active faults and earthquakes (Jarosiński, 2006). With these assumptions, we have calculated the strain change from eq. [6], for which $S_{h \text { min }}$ grows to the level of $S_{h \min }=S_{V}$, and call this strain difference the fracturing potential $\left(F r_{p o t}\right):$

$$
F r_{\text {pot }}=\frac{\left(S_{v}-S_{h \min }\right)\left(1-v_{h}^{2}\right)}{E_{h}}
$$

Independent calculations for the formations indicate that open stimulated fractures would compose a $19 e-5 \div 53 e-5$ part of the stimulated reservoir volume (SRV), depending on the formation. When integrating this value over $1 \mathrm{~km}$ of horizontal borehole interval it gives up to $0.5 \mathrm{~m}$ of open fracture space. To judge if this result is realistic from the point of view of the hydraulic fracturing treatment, we checked if the open fracture space is similar to the volume of fracking fluid used in well-recognized basins. Assuming that the SRV area for a $1 \mathrm{~km}$-long horizontal borehole is close to $0.25 \mathrm{~km}^{2}$ (vide Fig. 3) we estimated for a maximum storage scenario (120 m thick SRV) that such a borehole might consume $\sim 11,000 \mathrm{~m}^{3}$ of fracking fluid in average. This is within the broad range of values of fracking fluid volume of $8,000-24,000 \mathrm{~m}^{3}$ used in horizontal wells in US shale basins (Birdsell et al., 2015).

Moreover, we have considered that not all the fracturing potential is effectively available for $\mathrm{CO}_{2}$ storage. This is for the following reasons: (1) The flowback of fracking fluid due to partial closure of open fractures before the start of exploitation is estimated at $10-50 \%$. A mean value of $30 \%$ for fracking fluid flowback is assumed, with $70 \%$ effectiveness of fracking potential. (2) Part of this space is filled with proppant that usually constitutes several percent of the injected fracking fluid. Five percent of proppant admixture was adopted for further reduction of open fracture space; (3) Due to the reservoir pressure drop, the open fracture aperture gradually narrows during exploitation. In the case of proppant, this so-called embedment may lead to $20 \%$ reduction of fracture aperture in the study area (Masłowski, 2018). This value was taken for the calculations. Cumulating the effect of these reduction factors gives $52 \%$ of initially estimated fracturing potential volume.

RESULTS OF OPEN FRACTURE CAPACITY ASSESSMENT

The geomechanical approach used allows us to predict the effects of hydraulic fracturing in the vicinity of the SeqWell borehole. The "lithological sandwich" of our reservoir, in which organic-rich and grey shale formations are separated by unproductive organic-poor formations, needs special treatment to reach all prospective strata. Results of the $S_{h \text { min }}$ calculation (Fig. 6) show that the Prabuty Formation with low TOC and high carbonate content has the lowermost value of $S_{h \text { min }}(69 \mathrm{MPa})$, which is preferential for fracture initiation and for location of a horizontal borehole segment. The highest fracturing strain potential of this formation suggests that the fracture would not only easily initiate, but also propagate, across the Prabuty Fm. Those are the best conditions to trigger stimulation with the minimum losses of fracturing fluid energy, giving the maximum chance to reach the most promising organic-rich shale of the Sasino and Jantar formations located below and above the Prabuty Formation. After stimulation of these formations, the downward propagation of hydraulic fracture should cease at the top of the Kopalino limestone (Gajek et al., 2018). The fracturing propagation upwards to the Pelplin Fm. depends only on the applied fracturing conditions.

The volume of open fractures in each formation is dependent on both the formation thickness and the fracturing potential. From our calculations, a general rule can be derived that the organic-rich shale formations have lower storage efficiency in fractures than the organic-poor ones (Table 5). For example, the organic-rich shales have storage efficiencies of 0.08 and $0.12 \mathrm{~kg} / \mathrm{m}^{3}$, which is significantly lower than the $0.21 \mathrm{~kg} / \mathrm{m}^{3}$ of the less prospective organic-poor shale (Prabuty Fm.). These

Parameters used for fracture capacity calculation

\begin{tabular}{|l|c|c|c|c|c|c|}
\hline \multicolumn{1}{|c|}{ Formation } & $P_{O}[\mathrm{MPa}]$ & $E_{V}[\mathrm{MPa}]$ & $E_{H}[\mathrm{MPa}]$ & $v_{V}$ & $v_{H}$ & $\alpha$ \\
\hline Pelplin & 36.3 & 22,030 & 41,880 & 0.21 & 0.23 & 0.7 \\
\hline Pasłęk & 36.6 & 23,260 & 43,510 & 0.19 & 0.26 & 0.7 \\
\hline Jantar & 36.9 & 19,780 & 41,750 & 0.22 & 0.27 & 0.7 \\
\hline Prabuty & 37.0 & 27,400 & 42,000 & 0.21 & 0.24 & 0.7 \\
\hline Sasino & 37.1 & 19,120 & 41,970 & 0.19 & 0.26 & 0.7 \\
\hline
\end{tabular}




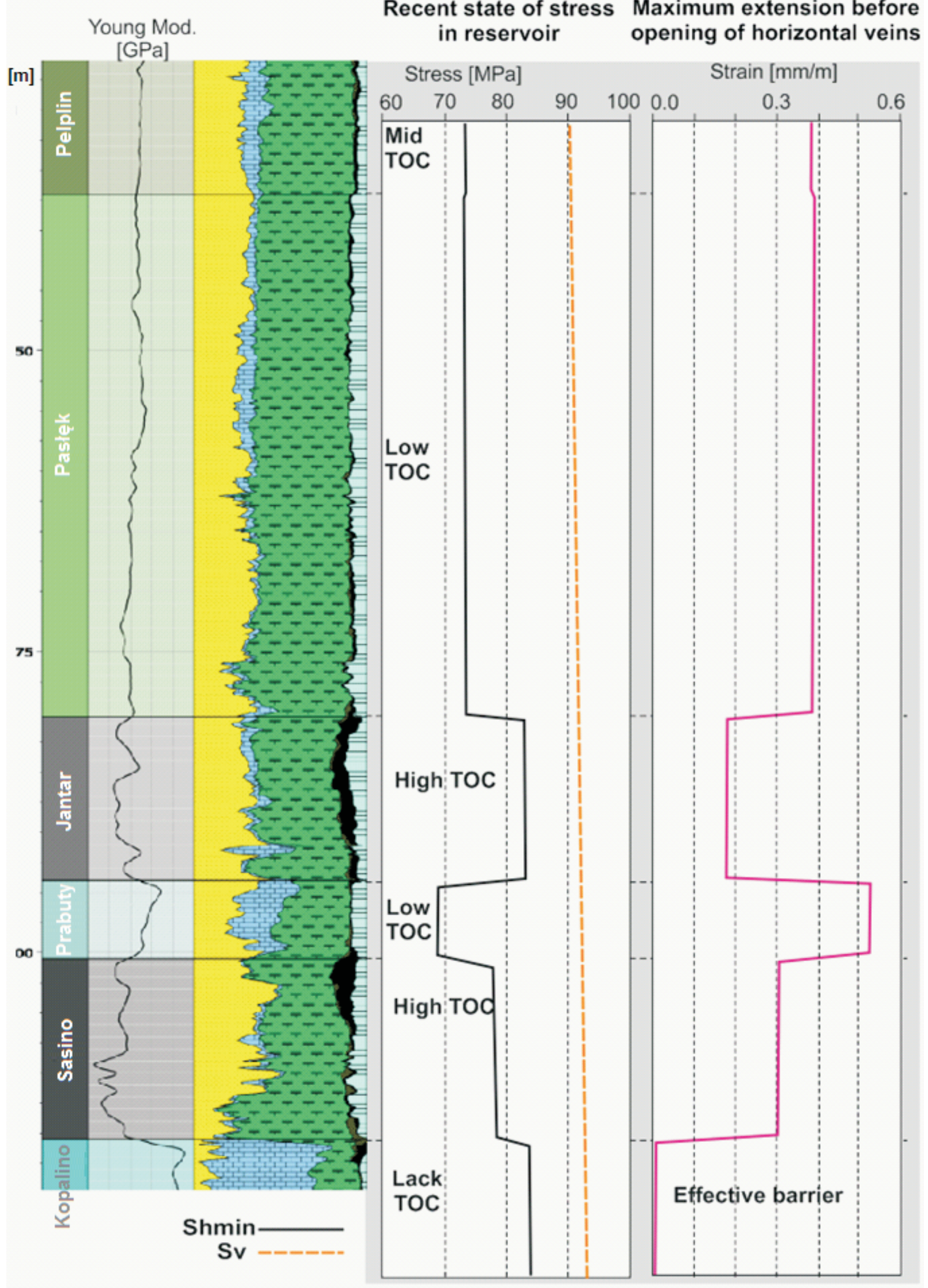

Fig. 6. The calculated mean values of minimum horizontal stress $\left(S_{h \text { min }}\right)$ and vertical stress $\left(S_{v}\right)$ for the formations analysed of the SeqWell borehole stacked with geophysical profiles of the Young's Modulus from acoustic logging and lithological composition from spectral logs ULTRA interpretation

The red curve on the right-hand-side diagram shows fracking potential changes in the borehole profile. Note that the upper part of the Pelplin Fm. is not shown 
Open fracture capacity of the formations

\begin{tabular}{|l|c|c|c|c|c|c|c|c|}
\hline Formation & $S_{V}$ [MPa] & $S_{h}[\mathrm{MPa}]$ & $\begin{array}{c}S_{V}-S_{h} \\
{[\mathrm{MPa}]}\end{array}$ & $\begin{array}{c}\text { Open } \\
\text { Fract. } \\
{[\mathrm{mm} / \mathrm{m}]}\end{array}$ & $\begin{array}{c}\text { Vol.frac. } \\
\text { fluid } \\
{\left[\mathrm{m}^{3} / \mathrm{km}^{2}\right]}\end{array}$ & $\begin{array}{c}\text { Vol. } \\
\text { reduct. } \\
\text { to 52 \% }\end{array}$ & $\begin{array}{c}\mathrm{CO}_{2} \\
\text { ton//km }\end{array}$ & $\begin{array}{c}\mathrm{CO}_{2} \\
\mathrm{~kg} / \mathrm{m}^{3}\end{array}$ \\
\hline Pelplin & 90.8 & 73.5 & 17.3 & 0.39 & 16031 & 8336 & 6419 & 0.16 \\
\hline Pasłęk & 91.4 & 73.1 & 18.2 & 0.39 & 17204 & 8946 & 6888 & 0.16 \\
\hline Jantar & 92.1 & 83.7 & 8.4 & 0.19 & 2444 & 1271 & 979 & 0.08 \\
\hline Prabuty & 92.4 & 68.7 & 23.7 & 0.53 & 3731 & 1940 & 1494 & 0.21 \\
\hline Sasino & 92.7 & 78.9 & 13.7 & 0.31 & 4575 & 2379 & 1832 & 0.12 \\
\hline
\end{tabular}

organic-rich shales have a higher level of $S_{h \text { min }}$ than the organic-poor shales, and thus a lower fracture potential. It is difficult to identify a single factor controlling the state of stress, which results from a combination of vertical and horizontal elastic moduli. In general, higher $S_{h \text { min }}$ values are recognized in the formations with a relatively higher content of weak components (organic matter and clay minerals, which increase the Poisson ratio). In contrast, the highest storage efficiency is attributed to the Prabuty Fm. with the lowest TOC content, which shows that the fracture capacity may partially compensate for a lower adsorption potential. Due to their greater thickness, a higher $\mathrm{CO}_{2}$ storage potential in fractures is attributed to the Pasłęk and Pelplin formations that show intermediate storage efficiency $\left(0.16 \mathrm{~kg} / \mathrm{m}^{3}\right)$.

\section{TOTAL CAPACITY OF THE $\mathrm{CO}_{2}$ SEQUESTRATION SYSTEM: DISCUSSION AND SUMMARY}

The results of the $\mathrm{CO}_{2}$ storage assessment were summarized, including the $\mathrm{CO}_{2}$ storage potential (capacity) with respect to unit area $\left(\mathrm{kt} / \mathrm{km}^{2}\right)$, and the storage efficiency per volume unit $\left(\mathrm{kg} / \mathrm{m}^{3}\right)$, both for separate shale formations and for storage intervals in the maximum and minimum scenarios (Table 6). By using the parameter of storage efficiency for shale successions, a rough extrapolation of storage capacity across an adjacent part of the Baltic Basin may be made, taking into account thickness changes of the formations examined.
In our study, we have checked to what extent consideration of the volume of stimulated fractures can affect the $\mathrm{CO}_{2}$ storage capacity. However, open fracture space is built, first of all, at the expense of gas-filled pore space, the compressibility of which is much higher than the compressibility of the mineral matrix. Thus this factor could be ignored if it were not for the fact that the accessibility of pore space is much smaller than with respect to the open fractures. While for pore space 10\% availability for $\mathrm{CO}_{2}$ was assumed, $100 \%$ of the fractures can be filled with $\mathrm{CO}_{2}$. Therefore, the capacity of pore space might be reduced additionally by $\sim 10 \%$ of the open fracture volume. This effect, although secondary, was included in the final version of storage capacity potential. However, by decreasing the final fracture space, instead of pore space, indicates how much capacity is added when fracture space is included in the storage assessment (Table 6).

For pore space capacity, the most relevant option (MICP) is presented. This option does not take into consideration the smallest nanopores where the sorption mechanism plays the decisive role in $\mathrm{CO}_{2}$ storage.

We have observed that different $\mathrm{CO}_{2}$ storage categories change their efficiency between organic-rich and organic-poor shales. In organic-rich shales, the adsorption mechanism decidedly prevails, which accounts for $84-88 \%$ of the total capacity of the Jantar and Sasino formations. On the other hand, in organic-poor shales adsorption accounts for $63-72 \%$ of the total $\mathrm{CO}_{2}$ capacity. Despite the significant differences between the organic-rich and organic-poor shale formations, this storage

Table 6

Results of the storage capacity assessment for the $\mathrm{CO} 2$ storage formations and intervals

\begin{tabular}{|c|c|c|c|c|c|c|}
\hline Formation & $\begin{array}{c}\text { Thickness } \\
{[\mathrm{m}]}\end{array}$ & $\begin{array}{l}\text { Adsorbed } \\
{\left[\mathrm{kt}^{\mathrm{k}} / \mathrm{km}^{2}\right]}\end{array}$ & $\begin{array}{l}\text { In pores } \\
{\left[\mathrm{kt}^{2} / \mathrm{km}^{2}\right]}\end{array}$ & $\begin{array}{c}\text { In fractures } \\
{\left[\mathrm{kt}^{\mathrm{k}} / \mathrm{km}^{2}\right]}\end{array}$ & $\begin{array}{l}\text { TOTAL Capac- } \\
\text { ity }\left[\mathrm{kt}^{\prime} / \mathrm{km}^{2}\right]\end{array}$ & $\begin{array}{l}\text { Efficiency } \\
{\left[\mathrm{kgCO}_{2} / \mathrm{m}^{3}\right]}\end{array}$ \\
\hline Pelplin1 & 41 & 32.5 & 7.0 & 5.8 & 45.3 & 1.1 \\
\hline Pasłęk & 44 & 26.3 & 6.3 & 6.2 & 38.8 & 0.9 \\
\hline Jantar & 13 & 28.9 & 3.2 & 0.9 & 33.0 & 2.5 \\
\hline Prabuty & 7 & 4.0 & 1.1 & 1.3 & 6.4 & 0.9 \\
\hline Sasino & 15 & 21.4 & 2.3 & 1.7 & 25.4 & 1.7 \\
\hline $\begin{array}{l}\text { Mean for max. } \\
\text { compl. }\end{array}$ & 120 & 113.1 & 19.9 & 15.9 & 148.9 & 1.2 \\
\hline $\begin{array}{l}\text { Mean for min. } \\
\text { compl. }\end{array}$ & 35 & 54.3 & 6.6 & 3.9 & 64.8 & 1.9 \\
\hline Marcellus & 38 & 72.3 & 39.7 & not included & 112.0 & 2.9 \\
\hline
\end{tabular}

The results are given for options: minimum (Jantar-Sasino) and maximum (Pelplin1-Sasino) storage thickness; $\mathrm{CO}_{2}$ storage capacity of unit area $\left(\mathrm{kt}^{2} / \mathrm{km}^{2}\right)$; and storage efficiency in unit volume $\left(\mathrm{kg} / \mathrm{m}^{3}\right)$. For comparison, results for Marcellus Shale are given after Godec et al. (2013b) 


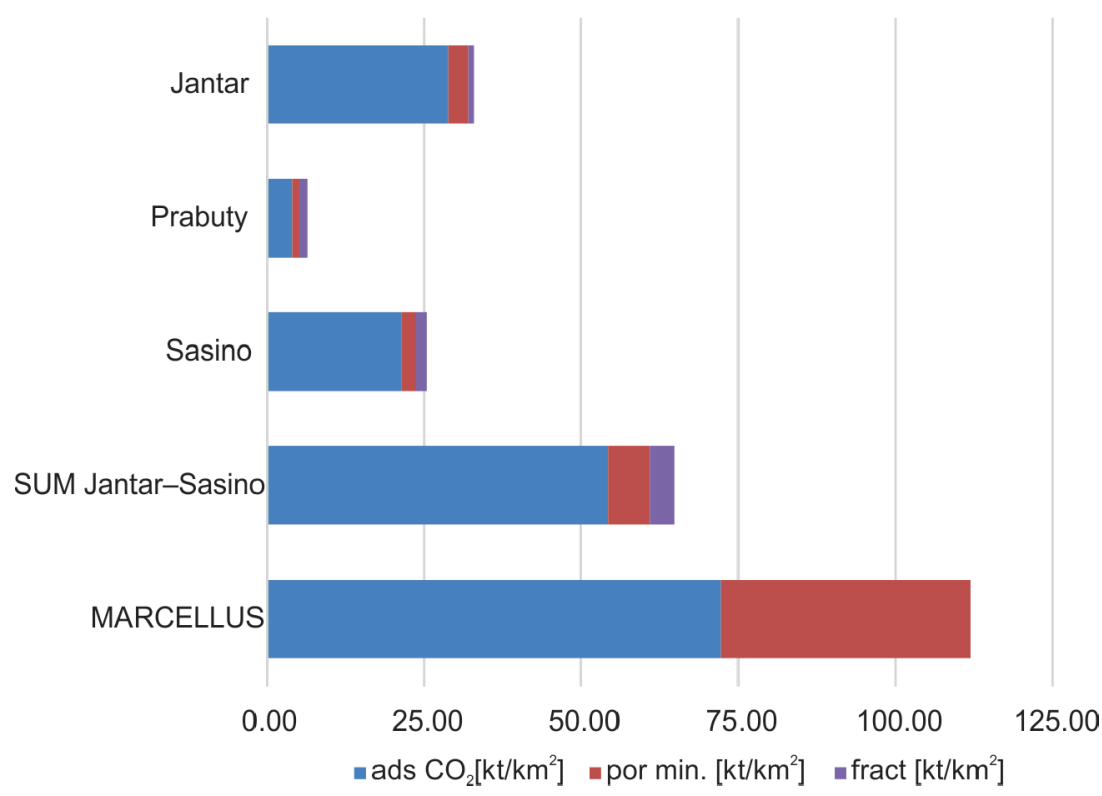

Fig. 7. A comparison of unit storage capacities of Pomeranian shales with a unit storage capacity of the Marcellus Shale

category can be considered the most important in each case, even in rocks with an average TOC content slightly $<1 \%$.

The $\mathrm{CO}_{2}$ storage capacity in the open pores varies within a broad range depending on the organic matter content. The organic-rich shale formations gain a share of pore capacity of $9 \div 10 \%$ of the total storage capacity, while in organic-poor shale, it is $15 \div 17$ (the highest value was obtained for the Prabuty Fm.). A similar relationship holds for the capacity of stimulated fractures. The maximum share of fracture capacity in organic-rich shales reaches only $7 \%$ of the total capacity while, in organic-poor shales the fracture capacity increases to $20 \%$.

Generally, for the maximum storage intervals (Pelplin1Sasino) it was found that the share of sorption storage is almost six times greater than the pore capacity and in the case of minimum storage intervals (Jantar-Sasino) that share is more than eight times greater. In turn, the share of stimulated fracture capacity is slightly smaller, to about two times smaller than the average capacity of the pore space. Adding the factor of storage in stimulated fractures to the static model results in increase of the total storage capacity by $8-10 \%$. This share could be larger in shale basins with a greater difference of stresses $\left(S_{h m i n}-S_{v}\right)$. Therefore, we suggest including this factor in static analyses of the $\mathrm{CO}_{2}$ storage in shales.

To bring our results into the broader context of $\mathrm{CO}_{2}$ storage potential in shale, we have compared our results with the Marcellus Shale, best-recognized in this respect (after Godec, 2013b, c, 2014). The comparison is made for the minimum thickness storage option (Jantar-Sasino; $35 \mathrm{~m}$ in thickness) with a better quality of reservoirs, which is closer to the published models of the Marcellus Shale (38 $\mathrm{m}$ in thickness on average). Since the properties controlling the quality of the shale reservoir determine also the capacity of $\mathrm{CO}_{2}$ storage, it is not surprising that all parameters are better for the Marcellus Shale. Our estimates (Fig. 7 and Table 6) show that the adsorption capacity in the US (Marcellus) is $\sim 30 \%$ higher than in the storage interval with the greatest potential in the Baltic Basin (Jantar-Sasino). Even more difference was noted in the storage capacity in the pores, which is $\sim 6$ times less than in the Marcellus Shale, and almost 4 times less if combined with the fracture capacity in the Baltic Basin (SeqWell). One of the rea- sons for this might be the shallower burial of the Marcellus Shale, which leads to less compaction and more pore space. Finally, the (unit) storage capacity of the Pomeranian shale is $\sim 60 \%$ of that for the Marcellus Shale. The ratio between the storage efficiency in these rocks is slightly greater and only the Jantar Formation (and probably the organic-rich part of the Sasino Formation as well) in the Baltic Basin is comparable to the Marcellus Shale in this parameter (Table 6). The latest conclusion might be surprising, taking into consideration that the TOC of the organic-rich Marcellus Shale is almost three times higher than in the organic-rich parts of the Jantar and Sasino formations (Ver Straeten et al., 2011; Leśniak, 2013; Popova, 2017). However, according to the results of Godec et al. (2013b) who studied the average value of $\mathrm{CO}_{2}$ sorption capacity of the Marcellus Shale (after the " $\mathrm{CO}_{2}$ storage, adsorbed" calculations in that study) is comparable to those of the Jantar and Sasino formations (see Table 2). Additionally, that value is about a half of the $\mathrm{CO}_{2}$ sorption capacity of the Marcellus Shale obtained from the Langmuir adsorption isotherm, as shown in Godec et al. (2013). We might infer that the storage efficiency of the Jantar and Sasino formations is comparable to the storage efficiency of the Marcellus Shale (most likely including both sweet spot and non-sweet spot areas) because the respective $\mathrm{CO}_{2}$ sorption capacities (that make dominant contributions to $\mathrm{CO}_{2}$ storage capacities) are comparable. On the other hand, a comparison of pore space capacities for the Marcellus Shale and the Jantar and Sasino formations suggests the free to adsorbed gas ratio might be several times higher in the case of the Marcellus Shale. These discrepancies reflect the differences between productive shales and those in which exploitation is currently not profitable.

Additionally, the SeqWell borehole and the reservoirs in question are located within the wet gas/condensate zone (Leśniak, 2013; Poprawa, 2020) and we have assumed in our study, for simplicity, that the gas in the shale formations is composed of pure methane. The effect of other, heavier hydrocarbons (ethane, propane, etc.) in the shale gas on the sorption mechanism of $\mathrm{CO}_{2}$ storage has not been evaluated in our study, and such an omission may be a source of uncertainty in storage capacity calculations. However, such an impact was 
also not considered in studies on the Marcellus Shale (Godec et al., 2013b, 2014), although the play area and reservoir analysed in these studies is located within dry gas, wet gas/condensate and oil zones (Popova, 2017).

When we extend our results (Table 6) to an area of $1000 \mathrm{~km}^{2}$ of Pomerania, where the shale properties and thickness of formations do not change significantly, we obtain a total $\mathrm{CO}_{2}$ storage capacity within the range of $60-180 \mathrm{Mt}$, depending on the storage option considered and the porosity model. That is comparable to the storage capacity of one moderate-sized structure within saline aquifers or an equivalent of storage capacity of the 1-3 largest hydrocarbon fields in Poland (Šliaupa et al., 2013; Wójcicki et al., 2014). There are several tens of structures of this size or greater in Poland. In other words, the storage capacity of $1000 \mathrm{~km}^{2}$ of the Pomeranian shale reservoir is merely $1 \%$ of the total $\mathrm{CO}_{2}$ storage capacity of saline aquifers and depleted conventional hydrocarbon fields in Poland. And, to achieve such an effect in shale, $\sim 4,000$ boreholes would be needed, with $1 \mathrm{~km}$ long horizontal sections.

\section{CONCLUSIONS}

$\mathrm{CO}_{2}$ storage prospects in the Lower Paleozoic shales of Pomeranian part of the Baltic basin are explored. Storage capacity analyses were carried out based on a modified static model approach, taking into account three storage categories: (1) by sorption, (2) in the remaining open pore space, and (3) in the space of stimulated fractures. The last option, not considered in conventional static models, was introduced based on assumptions formulated by the authors.

Scarce data on $\mathrm{CO}_{2}$ sorption in the shale formations examined have prompted us to use more numerous data concerning $\mathrm{CH}_{4}$ sorption. Determining the ratio between sorption parameters for both gases in similar samples has allowed the conversion of affinity sorption from $\mathrm{CH}_{4}$ to $\mathrm{CO}_{2}$. The estimated average results show that sorption in organic-rich shale formations is 3-4 times more effective than in organic-poor shale formations. However, due to the greater thickness of some formations with poor sorption properties, they might have still a considerable contribution to the storage capacity.

Our analyses indicate that the assessment of pore space capacity for $\mathrm{CO}_{2}$ storage is influenced mainly by the porosity model. The minimum porosity model (MICP porosimetry) is suggested to be more relevant for pore space capacity for $\mathrm{CO}_{2}$ storage than for the maximum model (open helium porosity). The storage efficiency in the pore space of organic-rich shale formations is always greater than in organic-poor shales, with a maximum ratio of $3 / 2$. Therefore, storage capacity in pores depends, to a major extent, on the thickness of the storage formation.

The scope of $\mathrm{CO}_{2}$ storage in stimulated fracture space is dependent on the ability of vertical fractures to be opened, which is limited by the stress shadowing effect. Using this rule, the stress model for the basin, and the anisotropic mechanical properties of shales, we have calculated the theoretical capacity of stimulated fractures for the formations investigated. The results indicate that organic-poor shale formations have the highest storage efficiency in fractures, which is about twice that of the organic-richest shale formations. Unlike the other storage categories, capacity in fractures inversely correlates with TOC content, but it is able to compensate, at most, for the differences in the pore space capacity.

The comparison of $\mathrm{CO}_{2}$ storage capacity between storage categories indicates that the sorption capacity is on average six to eight times greater than the capacity of pore space, for the maximum and the minimum storage interval respectively. Pore space is up to two times more capacious than the space of stimulated fractures.

A comparison with analogous results of the static model for the Marcellus Shale shows that the (unit) storage capacity of Pomeranian shales is significantly greater than of the Marcellus Shale while considering the $120 \mathrm{~m}$ thick maximum storage option (Table 6). However, while taking the more prospective minimum storage interval, $35 \mathrm{~m}$ thick (comparable to the Marcellus Shale), and an averaged value of pore capacity for the Pomeranian shale succession studied, the (unit) capacity of Pomeranian shales is only $\sim 60 \%$ of the capacity of the Marcellus Shale (Fig. 7 and Table 6). In the case of storage efficiency, the difference for the minimum storage option is slightly smaller, but only the Jantar Formation (and possibly the organic-rich part of the Sasino Formation) in the Pomeranian part of the Baltic Basin is comparable to the Marcellus Shale as regards this parameter. This can be explained by the sorption capacities of the Marcellus Shale and the Jantar and Sasino formations being comparable. However, the effective pore space capacities are not comparable and, most likely, neither are the free to adsorbed gas ratios, i.e. the Marcellus Shale includes far more free gas than the Jantar and Sasino formations, while the total gas content is several times higher within the Marcellus Shale.

The summary calculates that it would be necessary to develop $1000 \mathrm{~km}^{2}$ of the shale play in order to achieve a $\mathrm{CO}_{2}$ storage capacity comparable to the average size of a saline aquifer structure in Poland.

Acknowledgements. We are grateful to the Polish Oil and Gas Co. for sharing data, without which our analysis would not have been possible. We would also like to thank the two reviewers, P. Poprawa and E. Hough, whose comments significantly contributed to the improvement of the text of the article. This research was funded by Norway Grants in the Polish-Norwegian Research Program ShaleSeq project No POL-NOR/ $234198 / 100 / 2014$. The paper preparation was supported by the Polish Geological Institute grant No 62.9012.1939.00.0. Borehole log interpretation was done using the Techlog v. 2015.3 software package, which has been granted by Schlumberger Information Solutions.

\section{REFERENCES}

Andrews, I.J., 2013. The Carboniferous Bowland Shale gas study: geology and resource estimation. British Geological Survey for Department of Energy and Climate Change, London, UK.
Ahmed, U., Meehan, D.N., 2016. Unconventional Oil and Gas Resources: Exploitation and Development. CRC Press \& Taylor \& Francis Group, Boca Raton. 
Ambrose, R.J., Hartman, R.C., Diaz-Campos, M., Akkutlu, Y.I., Sondergeld, C.H., 2010. New Pore-scale Considerations for Shale Gas in Place Calculations. SPE 131772.

Birdsell, D.T., Rajaram, H., Dempsey, D., Viswanathan, H.S., 2015. Hydraulic fracturing fluid migration in the subsurface: A review and expanded modeling results. American Geophysical Union Publications, 51: 7159-7188.

Chojnacki, S., Marzec, D., 2013. Opracowanie badań geofizyki wiertniczej (in Polish). In: Dokumentacja prac geologicznych niekończących się udokumentowaniem zasobów złoża kopaliny wykonanych na obszarze koncesji ropy naftowej i gazu ziemnego Kartuzy-Szemud nr 72/2009/p, m., gm., Żukowo, Kartuzy, pow. kartuski, gdański z siedzibą w Pruszczu Gdańskim, kościerski, woj. pomorskie (ed. D. Strzelecka), Geofizyka Toruń, Toruń. Arch. CAG PIG, Warszawa, nr inw. 9901/2017.

Darłak, N., Kowalska-Włodarczyk, M., Such, P., 2011. Methodological aspects of porosity and pore space measurements in shale rocks. Nafta-Gaz, 67: 326-330.

Davies, R.J., Mathias, S.A., Moss, J., Hustoft, S., Newport, L., 2012. Hydraulic fractures: how far can they go? Marine and Petroleum Geology, 37: 1-6.

Economides, M.J., Nolte, K.G. (eds.), 2000. Reservoir Stimulation, 3rd Edition. John Wiley \& Sons, New York.

Edwards, R.W., Celia, M.A., Bandilla, K.W., Doster, F., Kanno, C.M., 2015. A model to estimate carbon dioxide injectivity and storage capacity for geological sequestration in shale gas wells. Environmental Science and Technology, 49: 9222-9229.

EIA (U.S. Energy Information Administration), 2013. Technically Recoverable Shale Oil and Shale Gas Resources: An Assessment of 137 Shale Formations in 41 Countries Outside the United States. June 2013. Washington DC.

Fisher, K., Warpinski, N., 2011. Hydraulic Fracture-Height Growth: Real Data. SPE 145949: 1-18.

Gajek, W., Trojanowski, J., Malinowski, M., Jarosiński, M., 2018. Results of downhole microseismic monitoring at a hydraulic fracturing site in Poland, Part 1: events location and stimulation performance. Interpretation, 6: SH39-SH48.

Gale, J.F.W., Laubach, S.E., Olson, J.E., Eichhubl, P., Fall, A., 2014. Natural fractures in shale: a review and new observations. AAPG Bulletin, 98: 2165-2216.

Godec, M., Hunter, J., Basava-Reddi, L., 2013a. Potential global implications of gas production from shales and coal for geological $\mathrm{CO}_{2}$ storage. Energy Procedia, 37: 6656-6666.

Godec, M., Koperna, G., Petrusak, R., Oudinot, A., 2013b. Potential for enhanced gas recovery and $\mathrm{CO}_{2}$ storage in the Marcellus Shale in the Eastern United States. International Journal of Coal Geology, 118: 95-104.

Godec, M., Koperna, G., Petrusak, R., Oudinot, A., 2013c. Assessment of factors influencing $\mathrm{CO}_{2}$ storage capacity and injectivity in Eastern U.S. Gas Shales. Energy Procedia, 37: 6644-6655

Godec, M., Koperna, G., Petrusak, R., Oudinot, A., 2014. Enhanced gas recovery and $\mathrm{CO}_{2}$ storage in gas shales: a summary review of its status and potential. Energy Procedia, 63: 5849-5857.

Goodman, A., Fukaib, I., Dilmore, R., Frailey, A., Bromhal, G., Soeder, D., Gorecki, Ch., Peck, W., Rodosta, T., Guthrie, G., 2014. Methodology for assessing $\mathrm{CO}_{2}$ storage potential of organic-rich shale formations. Energy Procedia, 63: 5178-5184.

Heller, R., Zoback, M., 2014. Adsorption of methane and carbon dioxide on gas shale and pure mineral samples. Journal of Unconventional Oil and Gas Resources, 8: 14-24.

Higgins, S.M., Goodwin, S.A., Donald, A., Bratton, T.R., Tracy, G.W., 2008. Anisotropic stress models improve completion design in the Baxter Shale. Presented at the SPE Annual Technical Conference and Exhibition, Society of Petroleum Engineers, doi: 10.2118/115736-MS

Huang, L., Ning, Z., Wang, Q., Zhang, W., Cheng, Z., Wu, X., Qin, H., 2018. Effect of organic type and moisture on $\mathrm{CO}_{2} / \mathrm{CH}_{4} \mathrm{com}-$ petitive adsorption in kerogen with implications for $\mathrm{CO}_{2}$ seques- tration and enhanced $\mathrm{CH}_{4}$ recovery. Applied Energy, 210: $28-43$.

IPCC, 2005. IPCC Special Report on Carbon Dioxide Capture and Storage. Prepared by Working group III of the Intergovernmental Panel on Climate Change (eds. B. Metz, O. Davidson, H.C. de Coninck, M. Loos and L.A. Meyer). Cambridge University Press, Cambridge, United Kingdom and New York, NY, USA.

Jarosiński, M., 2006. Recent tectonic stress field investigations in Poland: a state of the art. Geological Quarterly, 50 (3): 303-321.

Jarosiński, M., Wójcicki, A., 2016. $\mathrm{CO}_{2}$ storage in gas-bearing shales of the Baltic basin. EERA Conference 2016 in Birmingham, 24-25.11.2016 (presentation at the conference website: https://www.eera-set.eu/wp-content/uploads/X1_PGI-CO2-sEGR.pdf).

Jaworowski, K., 2002. Profil dolnego paleozoiku w północnej Polsce - zapis kaledońskiego stadium rozwoju basenu bałtyckiego (in Polish). Posiedzenia Naukowe Państwowego Instytutu Geologicznego, 58: 9-10.

Kalantari-Dahaghi, A., 2010. Numerical simulation and modelling of enhanced gas recovery and $\mathrm{CO}_{2}$ sequestration in shale gas reservoirs: a feasibility study, Society of Petroleum Engineers, Society of Petroleum Engineers - SPE International Conference on $\mathrm{CO}_{2}$ Capture, Storage, and Utilization 2010, doi: 10.2118/139701-MS

Kang, S.M., Fathi, E., Ambrose, R., Akkutlu, I., Sigal, R., 2011. Carbon dioxide storage capacity of organic-rich shales. SPE Journal, 16: 842-855.

Krzyżak, A.T., Habina-Skrzyniarz, I., Machowski, G., Mazur, W., 2020. Overcoming the barriers to the exploration of nanoporous shales porosity. Microporous and Mesoporous Materials, 298: 1387-1811.

Kurniawan, Y., Bhatia, S.K., Rudolph, V., 2006. Simulation of binary mixture adsorption of methane and $\mathrm{CO}_{2}$ at supercritical conditions in carbons. AIChE Journal, 52: 957-967.

Ladage, S., Berner, U., 2012. Abschätzung des Erdgaspotenzials aus dichten Tongesteinen (Schiefergas) in Deutschland. BGR, May 2012.

Leśniak, G. (ed.), 2013. Kompleksowa analiza i interpretacja badań rdzeni wiertniczych oraz płynów pochodzących z otworu Borcz-1 (in Polish). Instytut Nafty i Gazu, Kraków. In: Dokumentacja prac geologicznych niekończących się udokumentowaniem zasobów złoża kopaliny wykonanych na obszarze koncesji ropy naftowej i gazu ziemnego Kartuzy-Szemud nr 72/2009/p, m., gm., Żukowo, Kartuzy, pow. kartuski, gdański z siedzibą w Pruszczu Gdańskim, kościerski, woj. pomorskie (ed. D. Strzelecka). Arch. CAG PIG, Warszawa, nr inw. 9901/2017.

Lutyński, M., Waszczuk, P., Słomski, P., Szczepański, J., 2017. $\mathrm{CO}_{2}$ sorption of Pomeranian gas bearing shales - the effect of clay minerals. Energy Procedia, 125: 457-466.

Masłowski, M., 2018. Studies on the effect of the proppant embedment phenomenon on the effective packed fracture in shale rock. Acta Geodynamica et Geomaterialia, 15: 105-115.

Maxwell, S.C., 2011. Hydraulic fracture height growth. Recorder, 36: 18-22.

Middleton, R., Viswanathan, H., Curriera, R., Gupta, R., 2014. $\mathrm{CO}_{2}$ as a fracturing fluid: potential for commercial-scale shale gas production and $\mathrm{CO}_{2}$ sequestration. Energy Procedia, 63: 7780-7784.

Miljanović, E., Jabłoński, S., 2013. Końcowy raport desorpcyjny (in Polish). Geokrak Sp. z o.o., Kraków. In: Dokumentacja prac geologicznych niekończących się udokumentowaniem zasobów złoża kopaliny wykonanych na obszarze koncesji ropy naftowej i gazu ziemnego Kartuzy-Szemud nr 72/2009/p, m., gm., Żukowo, Kartuzy, pow. kartuski, gdański z siedzibą w Pruszczu Gdańskim, kościerski, woj. pomorskie (ed. D. Strzelecka). Arch. CAG PIG, Warszawa, nr inw. 9901/2017.

Modliński, Z. (ed.), 1982. Kościerzyna IG-1 (in Polish). Profile głębokich otworów wiertniczych Instytutu Geologicznego, 54.

Nuttall, B., Eble, C.F. Drahovzal, J.A., Bustin, M., 2005. Analysis of Devonian Black Shales for Potential Carbon Dioxide Sequestration and Enhanced Natural Gas Production, Report 
DE-FC26-02NT41442 prepared by the Kentucky Geological Survey, University of Kentucky, for the U.S. Department of Energy, National Energy Technology Laboratory, December 30.

PGI-NRI, 2012. Assessment of Shale Gas and Shale Oil Resources of the Lower Paleozoic Baltic-Podlasie-Lublin Basin in Poland. Warsaw, Poland.

Popova, O., 2017. Marcellus Shale Play, Geology review. EIA U.S. Energy Information Administration (https://www.eia.gov/ maps/pdf/MarcellusPlayUpdate_Jan2017.pdf).

Poprawa, P., 2020. Lower Paleozoic oil and gas shale in the Baltic-Podlasie-Lublin Basin (central and eastern Europe) - a review. Geological Quarterly, 64 (3): 515-566.

Poprawa, P., Šliaupa, S., Stephenson, R.A., Lazauskienė, J., 1999. Late Vendian-Early Palaeozoic tectonic evolution of the Baltic Basin: regional implications from subsidence analysis. Tectonophysics, 314: 219-239.

Rezaee, R., 2015. Fundamentals of Gas Shale Reservoirs. John Wiley \& Sons, Inc., Hoboken, New Jersey.

Rider, M., 1996. The geological interpretation of well logs. Whittles Publishing, Roseleigh House, Latheronwheel.

Schaef, H.T., Davidson, C.L., Owen, A.T., Miller, Q.R.S., Loring, J.S., Thompson, C.J., Bacon, D.H., Glezakou, V.A., McGrail, B.P., 2014. $\mathrm{CO}_{2}$ utilization and storage in shale gas reservoirs: experimental results and economic impacts. Energy Procedia, 63: 7844-7851.

Shi, J.Q., Durican, S., 2005. $\mathrm{CO}_{2}$ storage in deep unminable coal seams. Oil \& Gas Science and Technology - Revued'IFP, 60: 547-558.

Stadtmuller, M., Lis-Śledziona, A., Słota-Valim, M., 2018. Petrophysical and geomechanical analysis of the Lower Paleozoic shale formation, North Poland. Interpretation, 6: SH91-SH106.

Šliaupa, S., Lojka, R., Tasáryova, Z., Kolejka, V., Hladik, V., Kotulová, J., Kucharič, L., Fejdi, V., Wójcicki, A., Tarkowski, R., Uliasz-Misiak, B., Šliaupienè, R., Nulle, I., Pomeranceva, R., Ivanova, O., Shogenova, A., Shogenov, K., 2013. $\mathrm{CO}_{2}$ storage potential of sedimentary basins of Slovakia, the Czech Republic, Poland and the Baltic States. Geological Quarterly, 57 (2): 219-232.

Taggart, I., 2010. Extraction of dissolved methane in brines by $\mathrm{CO}_{2}$ injection: Implication for $\mathrm{CO}_{2}$ sequestration. SPE Reservoir Evaluation \& Engineering, 13: 791-804.
Taghichian, A., Zaman, M., Devegowda, D., 2014. Stress shadow size and aperture of hydraulic fractures in unconventional shales. Journal of Petroleum Science and Engineering, 124: 209-221.

Tao, Z., Clarens, A., 2013. Estimating the carbon sequestration capacity of shale formations using methane production rates. Environmental Science and Technology, 47: 11318-11325.

Trengove, R.D., Wakenham, W.A., 1987. The viscosity of carbon dioxide, methane, and sulfur hexafluoride in the limit of zero density. Journal of Physical and Chemical Reference Data, 16: 175-187.

Ver Straeten, C.A., Baird, G.C., Brett, C., Lash, G., Over, J., Karaca, C., Jordan, T., Blood, R., 2011. The Marcellus Subgroup in its type area, Finger Lakes area of New York and beyond. New York State Geological Association, Annual Meeting Guidebook, 83: 23-86.

Wei, G., Xiong, W., Gao, S., Hu, Z., Liu, H., Yu, R., 2013. Impact of temperature on the isothermal adsorption/desorption characteristics of shale gas. Petroleum Exploration and Development, 40: 514-519.

Wojtowicz, M., Jarosiński, M., 2019. Reconstructing the mechanical parameters of a transversely-isotropic rock based on log and incomplete core data integration. International Journal of Rock Mechanics and Mining Sciences, 115: 111-120.

Wójcicki, A., Nagy, S., Lubaś, J., Chećko, J., Tarkowski, R., 2014. Assessment of formations and structures suitable for safe $\mathrm{CO}_{2}$ storage (in Poland) including the monitoring plans (summary). PGI-NRI, Warsaw (final report of national programme available at PGI website: skladowanie.pgi.gov.pl).

Yuan, Y., Rezae, R., 2019. Comparative porosity and pore structure assessment in shales: measurement techniques, influencing factors and implications for reservoir characterization. Energies, 12: 2094.

Zhou, W., Zhang, Z., Wang, H., Yang, X., 2019. Molecular investigation of $\mathrm{CO}_{2} / \mathrm{CH}_{4}$ competitive adsorption and confinement in realistic shale kerogen. Nanomaterials, 9: 1646.

Zijp, M.H.A.A., Nelskamp, S., Doornenbal, J.C., 2017. Resource estimation of shale gas and shale oil in Europe. Report T7b of the EUOGA study (EU Unconventional Oil and Gas Assessment) commissioned by European Commission Joint Research Centre to GEUS. 